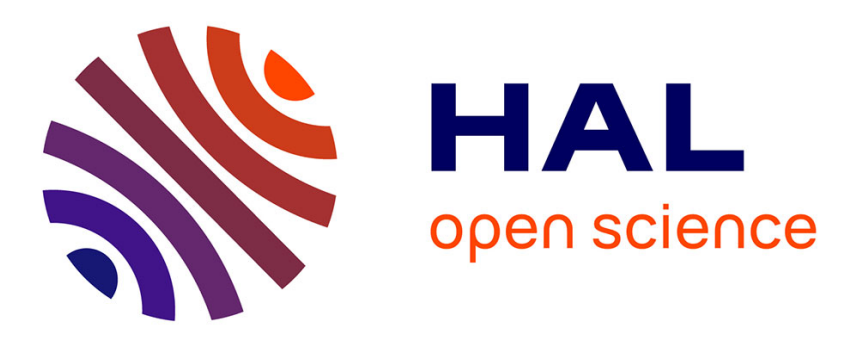

\title{
Review of tellurite glasses purification issues for mid-IR optical fiber applications
}

Frédéric Désévédavy, Clément Strutynski, Arnaud Lemière, Pierre Mathey, Grégory Gadret, Jean-charles Jules, Bertrand Kibler, Frédéric Smektala

\section{- To cite this version:}

Frédéric Désévédavy, Clément Strutynski, Arnaud Lemière, Pierre Mathey, Grégory Gadret, et al.. Review of tellurite glasses purification issues for mid-IR optical fiber applications. Journal of the American Ceramic Society, 2020, 103 (8), pp.4017-4034. 10.1111/jace.17078 . hal-03066371

\section{HAL Id: hal-03066371 \\ https://hal.science/hal-03066371}

Submitted on 16 Dec 2020

HAL is a multi-disciplinary open access archive for the deposit and dissemination of scientific research documents, whether they are published or not. The documents may come from teaching and research institutions in France or abroad, or from public or private research centers.
L'archive ouverte pluridisciplinaire HAL, est destinée au dépôt et à la diffusion de documents scientifiques de niveau recherche, publiés ou non, émanant des établissements d'enseignement et de recherche français ou étrangers, des laboratoires publics ou privés. 


\section{Review of tellurite glasses purification issues for mid-IR optical fiber applications}

Frédéric Désévédavy ${ }^{*}$, Clément Strutynski' ${ }^{a}$, Arnaud Lemière, Pierre Mathey, Grégory Gadret, Jean-Charles Jules, Bertrand Kibler and Frédéric Smektala

Laboratoire Interdisciplinaire Carnot de Bourgogne (ICB), UMR6303 CNRS - Université Bourgogne Franche-Comté, 21000 Dijon (France).

Abstract: We reviewed the tellurite glass purification studies performed over the last 20 years, in particular dealing with the mid-infrared transmission performances. Best results are obtained under rich $\mathrm{O}_{2}$ atmosphere with platinum crucibles although Gibbs energy calculations show that other crucibles material are possible such as gold or alumina. -From the point of view of the thermodynamics of involved oxidation reactions only, we identified the suitable conditions based on Gibbs energy calculations to be a synthesis temperature set above $900 \mathrm{~K}$ and a $\mathrm{O}_{2}$ pressure around $10^{5} \mathrm{~Pa}$. The performances of the different purification technics were also compared. Finally, we analyzed the tellurite fibers recently optimized for mid-infrared which present low attenuation up to $4 \mu \mathrm{m}$ allowing supercontinuum generation up to $5 \mu \mathrm{m}$.

\section{Introduction}

Tellurite glasses have been investigated for more than 150 years with first observations of the potential glass forming ability of tellurium oxide reported as early as $1834 .{ }^{1,2}$ The

a Clement Strutynski is now part of Institut de Chimie de la Matière Condensée de Bordeaux (ICMCB), CNRS, UPR 9048, Pessac, 33608, France

*Corresponding author: frederic.desevedavy@u-bourgogne.fr 
publication of Stanworth ${ }^{3}$ was the first one fully dedicated to tellurite glasses. Since then, many different $\mathrm{TeO}_{2}$-based glass systems have been studied and the first developments of tellurite fibers were reported in the 1990s. ${ }^{4}$

Tellurite glass fibers are of strong interest over a wide range of infrared (IR) wavelengths as waveguides or gain media for fiber lasers and fiber optical amplifiers based either on rare earth doping ${ }^{4-6}$ or Raman gain. ${ }^{7,8}$ In addition, tellurite glasses can be used as broadband laser sources through supercontinuum generation for medical, environmental, and defense applications. ${ }^{9-11}$ These glasses offer many advantages compared to other materials for the IR spectral region. For example, chalcogenides based on $\mathrm{S} / \mathrm{Se} / \mathrm{Te}$ can transmit light up to $20 \mu \mathrm{m}$ and beyond, depending on the composition. ${ }^{12}$ These materials have high optical nonlinearity, which makes them good candidates for mid-infrared (mid-IR) applications. However, their composition generally includes highly toxic elements such as arsenic. In addition, chalcogenide glasses have low physical strength and glass transition temperatures $\left(<200^{\circ} \mathrm{C}\right)$, together with poor resistance to moisture ${ }^{13-15}$, thus limiting possible applications. Halides and, in particular, fluoride glasses are another family of glasses useful in the Mid-IR thanks to their wide transmission window (up to $9 \mu \mathrm{m}$ ). Fluoride glasses can also act as hosts for rare earth doping. However, fluorides are physically weak compared to silica fibers and have a low glass transition temperature $\left(260^{\circ} \mathrm{C}\right)$. They also suffer from poor chemical durability, which results in very few glass compositions that can be handled at room atmosphere or processed into fibers. Thanks to their reasonably wide transmission window $(0.4-6.5 \mu \mathrm{m})$, moderate glass transition temperature $\left(<400^{\circ} \mathrm{C}\right)$, and high rare earth solubility, tellurite glasses offer an interesting compromise compared to fluorides and chalcogenides. Their range of possible chemical compositions facilitates optical design through refractive index and dispersion profile management. Moreover, tellurite glasses 
have the widest range of nonlinear responses (Raman gain, $\chi^{(3)}$ ) among heavy oxide glasses with higher refractive indices and nonlinear coefficients

The need to minimize water contamination in tellurite glasses was obvious and significant reductions in $\mathrm{OH}$ impurity contents were made in the $2000 \mathrm{~s}^{16-23}$ Tellurite glass purification, especially hydroxyl group removal, is of importance for many optical fiber applications. Because $\mathrm{OH}$ groups occupy a variety of different sites in $\mathrm{TeO}_{4}$ and $\mathrm{TeO}_{3}$ units, $\mathrm{OH}$-related absorption blocks transmission in a large band from $2.7 \mu \mathrm{m}$ up to $4 \mu \mathrm{m}$. Applications requiring transmission in the mid-IR, such as supercontinuum (SC) light sources, require a significant decrease of absorption in this range of wavelengths and extension of the transmission range to the multiphonon limit of $\mathrm{TeO}_{2}$-based materials (above $4.5 \mu \mathrm{m}$ ). ${ }^{24 \text {, }}$ ${ }^{25}$ As a consequence, only a few laboratories were able to demonstrate the spectral broadening up to this limit in the mid-IR. ${ }^{11,26-28}$ As a side note, rare earth-doped glasses used for emission around $2 \mu \mathrm{m}$ are also sensitive to $\mathrm{OH}$ content, which is responsible for the quenching of photoluminescence. ${ }^{29}$ The glass structure is modified by $\mathrm{OH}$ impurities, which lead to non-bridging oxygens, similar to alkali-containing glasses, and result in a decrease in network formation as well as a decrease of the transformation range viscosity and glass transition temperature. ${ }^{20}$ However, even under the worst conditions, i.e., when glass synthesis occurs in the ambient atmosphere, the $\mathrm{OH}$ content in glass remains low and in any case below 150 ppm by weight as discussed below.

Tellurite glasses can be purified either by physical dehydration through careful control of the synthesis conditions (e.g., atmosphere, drying of the precursors), or by the use of desiccating additives (e.g., halides such as $\mathrm{NaCl}, \mathrm{NaF}, \mathrm{ZnF}_{2}$ or $\mathrm{ZnCl}_{2}$ ). Another possibility to purify these glasses is to use reactive atmosphere processing (RAP) techniques. The purpose 
of this paper is to review different tellurite glass purification techniques and summarize the state-of-the art absorption/attenuation results.

\section{Composition}

Glass transparency is intrinsically governed by composition; tellurite glasses have been investigated because of their wide transparency in the mid-IR range. Long-wavelength transmission such as mid-IR is limited by absorption related to chemical bond vibrations, which are also called phonon energy. In the case of $\mathrm{TeO}_{2}$ based glass, the theoretical limit is set by $\mathrm{TeO}_{2}$ itself. Hence, for shifting the absorption limit as far as possible towards long wavelengths, the glass composition must only include constituents (modifiers and intermediates) whose inherent absorption wavelength is longer than that of tellurium (IV) oxide, which is a strategy used by several groups. ${ }^{11,30}$ Table 1 gathers fundamental absorptions and the three first harmonics of several oxides commonly found in glass compositions. Network modifiers such as alkalis, which promote formation of non-bridging oxygens, give rise to $\mathrm{TeO}_{3}$ units that absorb at $740 \mathrm{~cm}^{-1}$ compared to $650 \mathrm{~cm}^{-1}$ for $\mathrm{TeO}_{4}$ units. This shift results in a decrease in the mid-IR transmission window. Additionally, hydrogen can then associate with non-bridging oxygens to form hydroxyl groups, which give rise to unwanted absorption at the hydroxyl fundamental absorption peak around $3400 \mathrm{~cm}^{-1}$.

\section{Sources of Impurities}

Optical losses are largely determined by: 1) the concentration of impurities in the starting materials; 2) impurities imparted during glass synthesis; and 3) scattering from inclusions such as crystalline phases and bubbles. ${ }^{7,16,32}$ Among the extrinsic impurities present in the starting products, hydroxyl groups and 3d-transition metals actively absorb in the infrared and visible ranges and are particularly detrimental for optical applications in mid-IR. 
Tellurite glass preforms for optical fibers are usually manufactured by melt-casting from open platinum or gold crucibles. As such, the ambient atmosphere is the main source of $\mathrm{OH}$ impurities. Oxide precursors are another source of $\mathrm{OH}^{-}$contamination. Their metallic purity, mainly transition metals, is specified by the manufacturer, but other impurities such as water or carbon are not specified. The water content of the precursors depends on their synthesis process (extraction and refining). For example, carbonates are an important source of moisture. Contrary to the synthesis atmosphere for which we can control the water content the raw materials $\mathrm{OH}$ content is unknown and difficult to remove especially if it is chemisorbed. ${ }^{33,17}$ As a matter of facts, several study used homemade precursor to have a better control of their impurities content in order to improve optical properties of tellurite glass. $^{7,17,16}$

\section{Determination of $\mathrm{OH}$ concentration}

Hydroxyl groups strongly absorb in the mid-IR, between 2.7 and $4 \mu \mathrm{m}$. The extinction

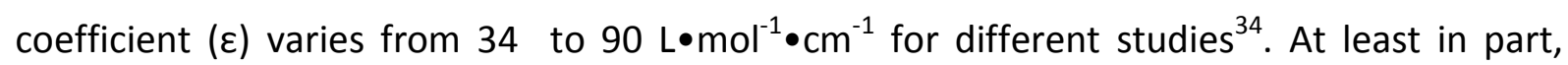
these discrepancies are related to calculating the extinction coefficient from either an exponential Beer Lambert law or an absorbance law. For example,35 absorbance measurements in silica glass resulted in an $\mathrm{OH}$ extinction coefficient of $42 \mathrm{~L} \cdot \mathrm{mol}^{-1} \cdot \mathrm{cm}^{-1}$ at $2.8 \mu \mathrm{m}$, in accordance with data published by other authors. ${ }^{34,} 35$ In the present work, absorption coefficients were determined using the exponential Beer Lambert law.

Because $\mathrm{OH}$ extinction coefficients have not been widely measured for tellurite glasses, values often come from measurements in silica glasses. However, data are available for tungstate tellurite compositions with an average value of $\varepsilon(\mathrm{OH})=109 \mathrm{~L} \bullet \mathrm{mol}^{-1} \bullet \mathrm{cm}^{-1}$ (from exponential Beer Lambert law) around $3000 \mathrm{~cm}^{-1}(3.33 \mu \mathrm{m}) .^{36,37}$ The $\mathrm{OH}$ extinction 
coefficient at $3 \mu \mathrm{m}$ in oxide glasses is often assumed to be $113 \mathrm{~L} \cdot \mathrm{mol}^{-1} \bullet \mathrm{cm}^{-138}$ which fits well with the one measured in tungstate tellurite glasses. ${ }^{36,37}$ We calculated the residual $\mathrm{OH}$ concentration $[\mathrm{OH}]$ (in wt ppm) using the extinction coefficient measured for tellurite tungstate glasses $\left(109 \mathrm{~L} \cdot \mathrm{mol}^{-1} \bullet \mathrm{cm}^{-1}\right)$ and the absorption coefficient measured around $3 \mu \mathrm{m}$ $\alpha_{\mathrm{OH}}$ in $\mathrm{cm}^{-1}$ into Equation 1:

$$
[O H]=\frac{\alpha_{O H} \times M_{O H}}{10^{-3} \times \rho \times \varepsilon(O H)}
$$

where $\mathrm{M}_{\mathrm{OH}}$ is the molecular weight in $\mathrm{g} \bullet \mathrm{mol}^{-1}$ of $\mathrm{OH}$ and $\rho$ is the volumetric mass density of tellurite glass in $\mathrm{g} \bullet \mathrm{cm}^{-3}$.

Removal of $\mathrm{OH}$ groups represents the most important challenge to maximize the transmission window of tellurite glasses and take full advantage of materials in bulk or as fibers. The most common approaches for purification of tellurite glasses are removing water and hydroxyl groups present in the precursors either before or during synthesis.

\section{Crucible and redox conditions of the synthesis atmosphere}

Different kinds of crucibles can be used for tellurite glasses synthesis. The common types are platinum $(\mathrm{Pt})$, gold $(\mathrm{Au})$ or corundum $\left(\mathrm{Al}_{2} \mathrm{O}_{3}\right)$. Using the Ellingham approximation, the standard Gibbs' free energy $\left(\Delta_{\mathrm{r}} \mathrm{G}^{0}\right)$ for oxidation of these metals (Pt, Au and Al) as a function of temperature was compared to the one for Te, see figure 1(a). The standard enthalpy and entropy of reaction were assumed to be independent of the temperature in ranges where no phase change occurred (see table 2).

At the phase change temperatures, data for fusion enthalpies and entropies were taken from. ${ }^{39-41}$ The calculations supported the use of platinum, gold or corundum crucibles. Tellurium oxidation is more favorable compared to $\mathrm{Pt}$ or $\mathrm{Au}$ oxidation, which means that $\mathrm{TeO}_{2}$ will not be reduced when heated in Pt or Au crucibles. As shown by the Ellingham 
diagram figure $1(\mathrm{a})), \mathrm{Al}_{2} \mathrm{O}_{3}$ reduction is not favored, which indicated that corundum should be inert in contact with $\mathrm{TeO}_{2}$ melts even in presence of Te traces.

By examining the evolution of the $\mathrm{O}_{2}$ equilibrium pressure $\mathrm{P}\left(\mathrm{O}_{2}\right)_{\text {eq }}$, deduced from $\Delta_{\mathrm{r}} \mathrm{G}^{0}$, as a function of temperature for oxidation of Te to $\mathrm{TeO}_{2}$ and $\mathrm{Pt}$ to $\mathrm{Pt}_{3} \mathrm{O}_{4}$ (figure $1(\mathrm{~b})$ ), suitable working oxygen activities can be estimated to ensure that $\mathrm{TeO}_{2}$ does not reduce to Te while simultaneously ensuring that the Pt crucible does not oxidize. Reduction of $\mathrm{TeO}_{2}$ is detrimental because it leads to an increase in background absorption. ${ }^{7,8}$ According to figure $1 \mathrm{~b}$, assuming a synthesis temperature of $700^{\circ} \mathrm{C}, \mathrm{O}_{2}$ pressures up to about $10^{5} \mathrm{~Pa}$ ( 1 bar), more specifically in the range of $9.840 \times 10^{4}<\mathrm{P}_{\mathrm{O}_{2}}<1.006 \times 10^{5}\left(10^{-0.007}<\left(\mathrm{P}_{\mathrm{O}_{2}} / \mathrm{P}^{\circ}\right)<10^{0.0025}\right)$, ensures that Pt does not oxidize and $\mathrm{TeO}_{2}$ does not reduce. For example, an atmosphere of pure oxygen at ambient pressure would avoid reduction of $\mathrm{TeO}_{2} \cdot{ }^{7,8}$ Pressures of $\mathrm{O}_{2}$ higher than about $10^{5} \mathrm{~Pa}$ should be avoided to prevent Pt oxidation. Since nitrogen does not react with tellurite glasses, dry air is another possible processing atmosphere. Indeed, for a total dry air pressure of $5 \times 10^{5} \mathrm{~Pa}, \mathrm{P}_{\mathrm{O}_{2}}$ is within the foregoing defined window.

Platinum is not totally inert in contact with $\mathrm{TeO}_{2}$, as mentioned by Churbanov et al. ${ }^{16,}$ ${ }^{17}$ Platinum has an effect on glass color due to a slight reaction of the crucible material under synthesis conditions, see figure 2 . For the same glass composition, synthesis in platinum crucible leads to a slightly yellow colored glass while a synthesis in gold crucible results in transparent glass. The color may be related to dissolved Pt, but does not appear to impact the IR range ${ }^{16,17}$. According to a study of phosphate-based glass ${ }^{42}, \mathrm{Pt}$ dissolves as $\mathrm{Pt}^{4+}$ under oxidizing conditions. This has also been observed for paratellurite $\left(\mathrm{TeO}_{2}\right)$ crystals $^{43}$ synthesis, where it was assumed that Pt was oxidized and then dissolved as $\mathrm{Pt}^{\mathrm{x}+}$ while some $\mathrm{TeO}_{2}$ was reduced to $\mathrm{TeO}$, which produces black inclusions. During the growth of these $\mathrm{TeO}_{2}$ crystals, $\mathrm{Pt}_{\mathrm{x}} \mathrm{Te}_{\mathrm{y}}$ alloys may also be formed. ${ }^{43}$ Single crystal growth experiments were performed under 
air, vacuum, or argon whereas $\mathrm{TeO}_{2}$ reduction can be avoided by working under an $\mathrm{O}_{2}$ rich atmosphere. The present calculations emphasize the need for an $\mathrm{O}_{2}$ rich atmosphere during tellurite glass synthesis. However, the mechanism of Pt interactions during glass synthesis still needs to be clarified. Similarly, gold may also dissolve into the melt by corrosion of the crucible at the synthesis temperature of $700^{\circ} \mathrm{C}^{44,45}$

\section{OH-groups content control}

One way to remove $\mathrm{OH}$ groups present in the starting materials is to heat treatment them. The precursors can be placed under vacuum or under a flow of dry oxygen to promote dehydration. ${ }^{17,46-50}$ However, figure $1 \mathrm{~b}$ shows that low $\mathrm{O}_{2}$ pressures, such as those produced in vacuum, result in $\mathrm{TeO}_{2}$ reduction. Thus, redox conditions should be considered when selecting drying conditions; obviously, $\mathrm{O}_{2}$ pressures far below $10^{5} \mathrm{~Pa}(1 \mathrm{bar}$ ) will lead to some $\mathrm{TeO}_{2}$ reduction, which will increase background absorption. Nevertheless, Mori and $\mathrm{al}^{7,8}$ showed that drying of starting materials can decrease losses in the near IR in tellurite glasses.

Another way to remove water and $\mathrm{OH}$ groups from tellurite glasses is to treat the liquid bath with reactive species during synthesis ${ }^{29,46,47,51}$. The usual process for the purification of tellurite glasses is to use desiccant halides reagents. Fluorinated or chlorinated forms of metals such as $\mathrm{ZnF}_{2}{ }^{19-21,50,52-57}, \mathrm{ZnCl}_{2}{ }^{58,59}, \mathrm{NaF}^{55}, \mathrm{NaCl}^{60}, \mathrm{PbCl}_{2}{ }^{50,60}$ or $\mathrm{BaF}_{2}, \mathrm{PbF}_{2}$ and $\mathrm{CaF}_{2}{ }^{50}$ can be mixed with oxide precursors to remove $\mathrm{OH}$ groups from tellurite glasses. These halide species react with free water or $\mathrm{OH}$ groups during synthesis to form $\mathrm{HCl}$ or $\mathrm{HF}$ gases, which then leave the liquid bath. A less common process is to carry out a chlorination/fluorination treatment of the starting powders before the synthesis. This can be done through the use of a solid reagent $\left(\mathrm{NH}_{4} \mathrm{~F}-\mathrm{HF}\right)$ or through reactive atmosphere 
processing (RAP) with a reactive gas, as detailed further in the section 7.3. These various purification techniques have extended light transmission in tellurite fibers above $4 \mu \mathrm{m}$, beyond the water-related absorptions.

\section{Purification processes}

Characteristic absorption bands found in tellurite glasses are listed in table 3 , including extrinsic absorption due to $\mathrm{OH}$ impurities and intrinsic absorption that limits glass transmission below $6.5 \mu \mathrm{m}$. The processes described below are perform by means of glove boxes or dedicated reactors.

\subsection{Controlled atmosphere}

Fusion of tellurite precursors must be done under an oxidizing and dry atmosphere. ${ }^{21,33} \mathrm{An}$ atmosphere rich in $\mathrm{O}_{2}$, but dry (water concentration less than $0.5 \mathrm{ppm}$ vol) enables reduction of the $\mathrm{OH}$ concentration by a factor of thirty (from $150 \mathrm{ppm}$ to $5 \mathrm{ppm}$ ) as compared to synthesis in open air, as shown in figure $3 .^{21,33}$ This reduction in $\mathrm{OH}$ concentration pushes the fiber transmission limit from 1.8 to $2.8 \mu \mathrm{m}$, as shown in table 4 , which reports methods implying only a controlled atmosphere (no reagents, no RAP and no homemade precursors) and figure 9. However, this synthesis route is not sufficient to reach the intrinsic limit of tellurite glass transmission that is controlled by multiphonon absorption resonances beyond $4.3 \mu \mathrm{m}$ (see Table 3). Indeed, an absorption coefficient of $0.25 \mathrm{~cm}^{-1}$ (calculated from Beer Lambert law, figure 3) corresponds to a loss level of about $108 \mathrm{~dB} / \mathrm{m}$, which prevents transmission of any signal above $3 \mu \mathrm{m}$ for a meter-long fiber segment.

\subsection{Homemade chemicals}

Mori et $\mathrm{al}^{7,8}$ developed tellurite glass fibers for telecom applications. To decrease optical losses in the telecom bands, they used homemade ultrapure $\mathrm{TeO}_{2}$. As a result, they 
obtained ultra-low loss tellurite fibers with an attenuation below $27 \mathrm{~dB} / \mathrm{km}$ at $1.23 \mu \mathrm{m}$, while it was about $900 \mathrm{~dB} / \mathrm{km}$ with commercial $\mathrm{TeO}_{2}$. By adding a vacuum degassing step of raw materials, the same loss level was reached at $1.55 \mu \mathrm{m}$. In this case, the $\mathrm{TeO}_{2}$ was fabricated from metallic Te using a wet chemical process. ${ }^{7,68}$

The Institute of Chemistry of High-Purity Substances has developed its own techniques, based on oxide distillation, to prepare $\mathrm{TeO}_{2}$ as well as other oxides. ${ }^{16,17,32,36,49 \text {, }}$ ${ }^{69,70}$ As reported in table 5, using such purified precursors decreased $\mathrm{OH}$ content and led to an absorption coefficient below $0.001 \mathrm{~cm}^{-1}$ between 2.7 and $4 \mu \mathrm{m}$, which means that the residual $\mathrm{OH}$ impurity concentration was below $0.1 \mathrm{ppm}$ wt.

Figure 4a gathers obtained bulk absorption coefficients for different studies that synthesized starting materials. As shown in figure $4 b$, tellurite glass preparation from ultrapure precursors is attractive for telecom applications. Note that Mori et $\mathrm{al}^{7}$ also reported telluritebased fiber Raman amplifiers as well as erbium doped fiber amplifiers. By synthesizing starting materials, bulk absorption coefficient corresponding to $\mathrm{OH}$ absorption as low as $0.001 \mathrm{~cm}^{-1}$ can be reached, which means that the corresponding fiber could exhibit losses that would not exceed $0.5 \mathrm{~dB} / \mathrm{m}$ between 2.7 and $4.3 \mu \mathrm{m}$. However, measurement of fiber attenuation in this wavelength range is not available for several reasons. First, bulk measurements are made on millimeter thick specimens, so the uncertainty increases when extrapolating the results to meter or kilometer lengths. Also, the thickness of the bulk is not sufficiently large to give an accurate loss value when the $\mathrm{OH}$ loss is reduced while possible contamination from polishing media may also affect measurements. ${ }^{60,16}$ Secondly, several fabrication steps are needed to obtain fiber. Fiber drawing, for example, requires heating of the glass preform above the glass transition temperature. Depending on process conditions 
(furnace atmosphere, time and rate of heating) and the glass composition, this step can be responsible for increasing losses.

As we show later in this paper, very few studies have reported fiber (i.e. at least meter-long specimens) loss measurements above $2.5 \mu \mathrm{m}$ and all of those results have been obtained through glasses purified by the use of desiccant reagents.

\subsection{Reactive atmosphere processing (RAP).}

Gaseous reagents can be added to the synthesis atmosphere during fusion or a separate pretreatment step to eliminate the water-related impurities from the raw materials. This method is rarely used because of the complexity of handling halogens like $\mathrm{F}_{2}$ or $\mathrm{Cl}_{2}$. For tellurite glasses, the majority of the reported studies have used chlorine. ${ }^{29,46,47,51}$ Another drawback of this method is unwanted halidation reactions that can occur in the melt in addition to the dehydration reactions. For instance, chlorine can also react to form chlorides resulting in an oxyhalide glass.

Ideally, chlorine will react with hydroxyls present in compounds such as $\mathrm{TeO}_{2}(\mathrm{OH})_{2}$, $\mathrm{Zn}(\mathrm{OH})_{2}$ and $\mathrm{Na}_{2} \mathrm{CO}_{3} \cdot 10 \mathrm{H}_{2} \mathrm{O} .{ }^{46}$ Ellingham diagrams were plotted considering the reaction of 1 mole of $\mathrm{Cl}_{2}$ with several hydrated precursors in the $\mathrm{TeO}_{2}-\mathrm{ZnO}-\mathrm{Na}_{2} \mathrm{O}$ (TZN) glass system, see figure 5. Thermodynamic data such as standard enthalpy of formation, standard entropy and standard heat of fusion were taken from published sources ${ }^{39-41}$ and hydrated precursors were considered when data were available. However, temperatures of phase transition or decomposition were not always available, so the validity of changes in Gibbs' energy at the higher temperature may be questionable. Results for $\mathrm{Zn}(\mathrm{OH})_{2}$ and $\mathrm{Na}_{2} \mathrm{CO}_{3} \cdot\left(\mathrm{H}_{2} \mathrm{O}\right)$ are plotted with dotted lines above their decomposition temperatures of 125 and $100^{\circ} \mathrm{C}$, respectively. ${ }^{39}$ These curves give information about the synthesis conditions that favor dehydration. According to the Ellingham diagrams (figure 5), $\Delta_{\mathrm{r}} \mathrm{G}^{\circ}$ is negative for all of the dehydration 
reactions with chlorides above $637 \mathrm{~K}$, indicating that dehydration is favorable above this temperature. The formation of $\mathrm{NaCl}$ and $\mathrm{ZnCl}_{2}$ are favorable at all temperatures.

Limiting the formation of oxyhalide species in the glass requires limiting the duration of the chlorine gas treatment, with no guarantee that chlorine will react exclusively with water or $\mathrm{OH}$ groups. The same considerations are valid for fluorine $\left(F_{2}\right.$, not shown here), which can form oxyfluoride glasses. Halide and oxyhalide glasses are more sensitive to the ambient atmosphere, especially moisture, which makes these materials difficult to process, particularly for fiber drawing ${ }^{72}$.

Figure 6 shows the absorption coefficient obtained for glasses using RAP; the lowest $\mathrm{OH}$ absorption coefficient was $0.05 \mathrm{~cm}^{-1}$ obtained by Joshi et al ${ }^{46}$ corresponding to 21.7 $\mathrm{dB} / \mathrm{m}$. However, to the best of our knowledge, no reports of fiber produced from glass prepared through RAP have been published. Moreover, the value of $21.7 \mathrm{~dB} / \mathrm{m}$ is still too high to consider meter-long fiber applications at $3 \mu \mathrm{m}$ and above.

\subsection{Desiccant reagents}

The addition of solid halogen-containing compounds is preferred to avoid using toxic and reactive halogen gases in the processing of tellurite glasses. ${ }^{60}$ This technique consists of using a reagent which will react with free water or $\mathrm{OH}$ groups in the starting chemicals and glass batch during synthesis. Halide dehydrating reagents that have been used include $\mathrm{ZnF}_{2}$, $\mathrm{PbCl}_{2}$ and $\mathrm{TeCl}_{4}$. As shown in table 7, this is the most common purifying process for tellurite glasses and the most used halide is $\mathrm{ZnF}_{2}$, which reduces $\mathrm{OH}$ content by Reaction (2). ${ }^{19}$ Fluorides are known to be highly reactive with water and $\mathrm{OH}$ groups. ${ }^{73}$ One of the reaction products is zinc oxide, which is part of several tellurite glass compositions. ${ }^{19} 2[\equiv T e-O H]+$ $Z n F_{2} \rightarrow \equiv T e-O-T e \equiv+Z n O+2 H F_{(g)}($ 


$$
2[\equiv T e-O H]+Z n F_{2} \rightarrow \equiv T e-O-T e \equiv+Z n O+2 H F_{(g)}
$$

In addition, halide reagents can reduce the water in the glass melting atmosphere (Eq (3)), which prevents hydrolysis of the melt (eq (4)).

$$
\begin{gathered}
\mathrm{ZnF}_{2}+\mathrm{H}_{2} \mathrm{O} \rightarrow \mathrm{ZnO}+2 \mathrm{HF}_{(g)} \uparrow \quad(3) \\
\equiv \mathrm{Te}-\mathrm{O}-\mathrm{Te} \equiv+\mathrm{H}_{2} \mathrm{O} \leftrightarrow 2[\equiv \mathrm{Te}-\mathrm{OH}]
\end{gathered}
$$

Reactions with halides can also impact the crucible choice. To address that, we have plotted an additional Elligham-like diagram using the same methodology as described above. In this case, the reaction of 1 mole of $\mathrm{ZnF}_{2}$ with four hydrated precursors of the TZN glass system were considered, see figure $7(a) .{ }^{39-41} \mathrm{TeO}$ was included in this analysis as it may be present in the starting powder and increases background attenuation ${ }^{7}$. Hydrated precursors for which thermodynamic data were available were analyzed, but heats of fusion and temperatures of phase transitions or decomposition were not available for these compounds. These predictions provide information about the synthesis conditions that favor dehydration. The curve relative to sodium carbonate decahydrate $\left(\mathrm{Na}_{2} \mathrm{CO}_{3} \cdot 10 \mathrm{H}_{2} \mathrm{O}\right)$ is not presented here contrary to the work of Joshi et $\mathrm{al}^{46}$ because it decomposes at $34^{\circ} \mathrm{C}$ according to. ${ }^{39}$ The curve for sodium carbonate monohydrate $\left(\mathrm{Na}_{2} \mathrm{CO}_{3} \cdot \mathrm{H}_{2} \mathrm{O}\right)$ is plotted with a dashed line above $100^{\circ} \mathrm{C}$, which is its reported decomposition temperature. ${ }^{39}$ As a result of decompositions and gaps in data, the thermodynamic considerations presented here are notional and not intended to be quantitative. It is worth noting that decomposition of hydrated carbonates produces water molecules that can then react with other compounds, especially $\mathrm{TeO}_{2}$ (see figure 7b). Our goal here is to provide information about thermal/gas atmosphere conditions, which allow for dehydration of the starting materials used for tellurite glass synthesis. To that end, $\Delta_{\mathrm{r}} \mathrm{G}^{\circ}$ was calculated from room temperature to $850^{\circ} \mathrm{C}$, 
which corresponds to the range of temperatures used for tellurite glass synthesis. According to figure $7(a)$ the four dehydrating reactions are favored at higher temperatures. At the usual synthesis temperature (around $850^{\circ} \mathrm{C}$, see table 7$), \Delta_{\mathrm{r}} \mathrm{G}^{\circ}$ is significantly negative $\left(\Delta_{\mathrm{r}} \mathrm{G}^{\circ}<\right.$ $-150 \mathrm{~kJ} / \mathrm{mole}$ ), which indicates that dehydration is favored for all the four hydrated starting products. Moreover, according to figure $7 \mathrm{~b}$, above $563 \mathrm{~K}\left(290^{\circ} \mathrm{C}\right)$ the hydration of $\mathrm{TeO}_{2}$ is not favorable. The same figure shows that Reaction (3) is favored above $823 \mathrm{~K}\left(550^{\circ} \mathrm{C}\right)$, which means that $\mathrm{ZnF}_{2}$ is an effective additive for removing water. Hence, synthesis needs to occur above $550^{\circ} \mathrm{C}$, and then glasses need to be quenched through the zone where dehydration is thermodynamically favored and kinetically significant to maximize the dehydration processes. Figures 7 (c) and (d) show the log of the HF pressure and the equilibrium constant as functions of temperature. The equilibrium constant depends mainly on the gas pressures when the activities of the solid and pure liquid phases are assumed to be 1 .

Figures $7(\mathrm{a})$ and $7(\mathrm{c})$ show that high temperature and moderate $\mathrm{HF}$ pressure favor the reaction with $\mathrm{ZnF}_{2}$. This means that evacuating the $\mathrm{HF}$ as it is formed, which is the case when glass is prepared under flowing gas, will shift the equilibrium toward the dehydration. This may be problematic when working under gas pressure in static conditions. ${ }^{83}$ In this case, a large reactor volume or regular refreshing of the gas is required to maintain a low partial pressure of $\mathrm{HF}$. In the case of the reaction with $\mathrm{TeO}_{2}(\mathrm{OH})_{2}$, interpretation of the equilibrium constant evolution is not as apparent. Experimentally, only the $\mathrm{O}_{2}$ pressure can be controlled. In many studies, pure $\mathrm{O}_{2}$ was used, which means that the $\mathrm{O}_{2}$ pressure is slightly above $10^{5} \mathrm{~Pa}$ ( 1 bar). As in flow conditions, $\mathrm{HF}$ is evacuated as it is formed and its pressure should stay as low as possible to allow for $\mathrm{O}_{2}$ pressure to stay above 1 bar. To estimate the $\mathrm{O}_{2}$ pressure threshold, we consider the worst case, i.e. the formation of all the HF at the same time, which means an instantaneous reaction of all the desiccant reagents. The 
experimental conditions used in our glass preform fabrication can be approximated using 5 at\% $\mathrm{ZnF}_{2}$ in $40 \mathrm{~g}$ of $\mathrm{TZN}$ glass $\left(80 \mathrm{TeO}_{2}-10 \mathrm{ZnO}-10 \mathrm{Na}_{2} \mathrm{O}, \%\right.$ at) in a volume of $3 \mathrm{~L}$. For this estimation, activity of non-gaseous species was assumed to be 1 and gases were assumed to be ideal. At $973 \mathrm{~K}\left(700^{\circ} \mathrm{C}\right)$, the $\mathrm{HF}$ pressure would be $75000 \mathrm{~Pa}(0.75$ bars) leading to a threshold $\mathrm{O}_{2}$ pressure of $315000 \mathrm{~Pa}$ (3.15 bars, calculated from the equilibrium constant shown in figure $7(d))$, which means that above this threshold the reactions that remove hydroxyls are no longer favored. As mentioned above, working under flow conditions, allows for $\mathrm{HF}$ removal as it is formed and guarantees that the $\mathrm{O}_{2}$ pressure is well below the calculated threshold as long as all of the $\mathrm{ZnF}_{2}$ does not react instantaneously.

Based on previous reports and our own work ${ }^{83,84}$, fluorides (especially $\mathrm{ZnF}_{2}$ ) seem to be more effective than other halides, see figure 8 . Feng and Liao ${ }^{60,75}$ used up to 20 at\% halides to reduce $\mathrm{OH}$ absorption, while Savelii, Strutynski, or Rhonehouse $21,28,30$ used no more than 5 at\% of $\mathrm{ZnF}_{2}$. According to figure 8(a) and 8(c), lower amounts of reagents (e.g., $<5$ at\%) are sufficient to maximize the decrease in $\mathrm{OH}$-absorption. Moreover, with an optimized process, up to 5 at\% of $\mathrm{ZnF}_{2}$ does not degrade glass properties as suggested by ${ }^{30}$ and shown by the refractive index and $\mathrm{T}_{\mathrm{g}}$ measurements of Strutynski et $\mathrm{al}^{28}$, even if some residual halide is present in these glasses. A non-zero residual amount of fluoride indicates that substantially all of the $\mathrm{OH}$ groups were removed. In this case, this small residual amount of fluoride does not degrade the chemical durability of the glass nor does it lead to breakage of tellurium oxygen bonds that would weaken the glass network and increase absorption in the mid-IR. Higher initial amounts of halide can show better results on bulk sample as reported by $\mathrm{Jia}^{10,78}$, see figure 8 (c). However, glasses with substantial halide content are no longer tellurites, but fluorotellurites, since the only oxide in the composition is the glass former $\left(\mathrm{TeO}_{2}\right)$ while the other constituents are fluorides. 
The addition of fluorides leads to composition modifications as shown by decreases in refractive index and $T_{g}$ along with changes in Raman spectra. ${ }^{19,21,30,52}$ Fluoride additions can also prevent or complicate post processing of the glass including fiber drawing. Any excess halide becomes part of the glass network and halide glasses, especially fluorides, are very difficult to draw. ${ }^{72}$ Additions of 5 and 10 at $\mathrm{ZnF}_{2}$ to a TZN glass revealed that the composition containing $10 \% \mathrm{ZnF}_{2}$ is much more difficult to process and yields fibers with losses that were too high to be measured by the cut back technique using specimens of 20 $\mathrm{cm}$ long. ${ }^{83,84}$ Very few studies have reported fiber drawing and attenuation measurements on tellurite glass fibers prepared through reagent additions, especially for wavelengths above $3 \mu \mathrm{m}$. Figure 9 summarizes reported attenuations for these tellurite fibers made from a glass prepared through the desiccant reagent technic.

Recently Yao et al. prepared a step index fiber based on fluorotellurite glasses (for core and cladding) that exhibited low losses between 1 and $5 \mu \mathrm{m}^{82}$ as shown by the blue curve in figure 9a. However, IR transmission of fluorotellurite glasses is limited by $\mathrm{TeO}_{2}$ phonon resonances, which occurred at shorter wavelengths than fluoride alone, while the nonlinearity was reduced compared to tellurite glasses. Most fluorotellurite glasses suffer from poor stability against crystallization and water attack, leading to delicate glass processing, especially the fiber drawing. However, for some compositions, the mechanical and thermal stability of fluorotellurites can be better than for fluoride and chalcogenide glasses. In addition, fluorotellurites can also have a $\mathrm{T}_{\mathrm{g}}$ above $400^{\circ} \mathrm{C}$, which is higher than usual fluoride, chalcogenide and tellurite glasses. ${ }^{82}$ When using fluorides as desiccant reagents, the goal is for the final glass to not contain any fluoride. ${ }^{30}$ Thus, the final glass is expected to be a pure oxide one, in the present case a tellurite glass. 
Considering $\mathrm{OH}$ reduction and infrared signal transmission above $3 \mu \mathrm{m}$, the best attenuation has been reported by Strutynski et al. in step index tellurite fibers ${ }^{27,} 28$ (orange curve in figure $9(\mathrm{a} \& \mathrm{~b}))$. The core of this fiber was a TZN glass with 5 at $\%$ of $\mathrm{ZnO}$ replaced by $\mathrm{ZnF}_{2}$. Attenuation was less than $1 \mathrm{~dB} / \mathrm{m}$ from the visible up to $3 \mu \mathrm{m}$, and the attenuation stayed below $8 \mathrm{~dB} / \mathrm{m}$ up to $4 \mu \mathrm{m}$. Absorption above $4 \mu \mathrm{m}$ is due to an intrinsic limitation based on $\mathrm{TeO}_{2}$ multiphonon absorption. Note that when authors have not specified whether their measurements were made on bulk glass or fibers, data were not plotted in figure 9, such as for reference. ${ }^{11}$ Based on such optimized fiber transmissions above $3 \mu \mathrm{m}$, enhanced SC generation in tellurite fibers was demonstrated by different teams, as depicted in figure 10.

More specifically, these tellurite fibers exhibited signal transmission up to $4 \mu \mathrm{m}$ with loss levels below $10 \mathrm{~dB} / \mathrm{m}$ from visible up to $4 \mu \mathrm{m}$. In each cases, $\mathrm{ZnF}_{2}$ was used as desiccant reagent. ${ }^{27,28,30}$ Two SC spectra were generated with the same pumping laser source in two different fibers, which correspond to red and black plots in figure 10. These results obtained by two different collaborations underline the effectiveness of tellurite $\mathrm{OH}$ removal for mid-IR SC generation. Note that we recently obtained a similar SC in another tellurite glass fiber prepared through the same process, but with lower coupled peak power. ${ }^{9}$ The larger power spectral density is due to the ps pumping, this is why dynamic is larger ( $40 \mathrm{~dB})$ for the green curve than for the red and black ones (20 dB). Figure 10 also shows the SC generated in the tapered fluorotellurite ${ }^{85}$ (blue curve) fiber whose losses are presented in blue in figure 9a. The addition of more than 20 at\% fluoride reduced losses in the mid-IR spectral range $(<2.3$ $\mathrm{dB} / \mathrm{m}$ from 1.1 and $4.5 \mu \mathrm{m})$. On the other hand, despite the use of a much higher peak power pump (160 kW launched), the generated SC does not extend further into the IR, which may be due to the lower nonlinear absorption properties of oxyfluorides compared to 
pure tellurite glasses. In our case, these results were obtained with alkali containing glasses. However, as discussed above, alkalis have to be removed from glass to optimize mid-IR glass transmission because they promote formation of non-bridging oxygens that are responsible to the blue shift of phonon absorption and an increased sensitivity to hydroxyl-group absorption. Therefore, an alkali-free tellurite glass will further improve the fiber attenuation and the mid-IR SC extension.

Other processes have been used for glass synthesis including chemical vapor deposition (CVD) and microwave melting. CVD is complex and has primarily been used for silica glasses for the manufacture of telecommunication fibers. Microwave melting has been implemented in multicomponent glasses such as silicates ${ }^{86}$ and chalcogenides ${ }^{87}$. In both cases, microwave melting led to lower $\mathrm{OH}$ contents compared to furnace melted glasses without additional purification steps. According to ${ }^{88}$, zinc oxide is a strong microwave absorber at $2.45 \mathrm{GHz}$ above $600^{\circ} \mathrm{C}$. Therefore, tellurite glasses containing $\mathrm{ZnO}$ can be synthesized by combining conventional and microwave heating. However, to the best of our knowledge, no results on tellurite glasses have been reported on microwave-assisted synthesis.

\section{Summary and outlook}

Gibbs free energy calculations in the framework of Ellingham approximations provide valuable information about synthesis conditions of tellurite glasses, as well as for dehydration reactions for water-containing raw materials. Synthesis temperatures above 900K together with $\mathrm{O}_{2}$ pressures approaching $10^{5} \mathrm{~Pa}$ ( 1 bar) ensure oxides precursors, such as $\mathrm{TeO}_{2}$, do not reduce and oxidation of platinum crucibles is avoided. Purification of tellurite glasses requires processing under a controlled atmosphere to favor dehydration and to 
eliminate moisture from the synthesis atmosphere, and usually glove boxes or dedicated reactors are used. Higher purity extends the tellurite fiber transmission window to above 4 $\mu \mathrm{m}$, to the intrinsic multiphonon absorption limit. One purification method is to use ultrahigh purity precursors to perform the synthesis, which results in bulk samples containing the lowest $\mathrm{OH}$ levels ever reported. However, no absorption data at $3 \mu \mathrm{m}$ and above have been published on fiber resulting from this glass synthesis process. This could be due to the difficulty to prepare enough of highly pure precursor for a fiber glass preform combined with additional processing steps responsible for impurities in the resulting fibers. Indeed, such ultra-high purity raw materials are not commercially available and raw material purification is resource intensive.

This review of synthesis and purification processes reveals that the best combination of fiber drawing and mid-IR optical transmission for tellurite glasses are obtained when using a zinc difluoride as desiccant reagent, avoiding its excess not to alter the final glass composition, and ensuring removal of $\mathrm{HF}$ as it is formed. Such tellurite fibers exhibit an infrared supercontinuum extending from $1 \mu \mathrm{m}$ up to $5 \mu \mathrm{m}$. This opens up new possibilities for applications of tellurite fibers such as absorption spectroscopy ${ }^{89}$, frequency comb generation for high resolution spectroscopy ${ }^{90-92}$, optical coherence tomography $y^{93,94}$, food quality analysis $^{95}$, biomedical endoscopy ${ }^{96-99}$ and atmospheric gas sensing. ${ }^{81,100}$

\section{Acknowledgements}

We acknowledge the financial support of the French Investissements d'Avenir program (ISITE-BFC ANR-15-IDEX-0003, SCUVIRA project), the French ANR through the Project TRAFIC ANR-18-CE08-0016-03, the European program FEDER and the Council of the French Bourgogne Franche-Comté Region through the grant "Jeune Chercheur Entrepreneur" scheme. 


\section{References}

1. Berzelius J. Tellurite Glasses. Annal Physike Chemie. 1834; 32:577.

2. Lenher V, Wolesensky E. A study of the metallic tellurites. Journal of the American Chemical Society. 1913; 35(6): 718-733.

3. Stanworth J. Tellurite glasses. 1952.

4. Wang JS, Vogel EM, Snitzer E. Tellurite glass: a new candidate for fiber devices. Optical materials. 1994; 3(3): 187-203.

5. Kumar A, Rai D, Rai S. Optical studies of $\mathrm{Eu}^{3+}$ ions doped in tellurite glass. Spectrochimica Acta Part A: Molecular and Biomolecular Spectroscopy. 2002; 58(10): 21152125.

6. El-Mallawany RA. Tellurite glasses handbook: physical properties and data. CRC press; 2002.

7. Mori A. Tellurite-based fibers and their applications to optical communication networks. Journal of the Ceramic Society of Japan. 2008; 116(1358): 1040-1051.

8. Mori A, Kobayashi K, Yamada M, Kanamori T, Oikawa K, Nishida Y, et al. Low noise broadband tellurite-based Er3+-doped fibre amplifiers. Electronics Letters. 1998; 34(9): 887888 .

9. Froidevaux $P$, Lemière $A$, Kibler $B$, Désévédavy $F$, Mathey $P$, Gadret $G$, et al. Dispersion-Engineered Step-Index Tellurite Fibers for Mid-Infrared Coherent Supercontinuum Generation from 1.5 to $4.5 \mu \mathrm{m}$ with Sub-Nanojoule Femtosecond Pump Pulses. Applied Sciences. 2018; 8(10): 1875.

10. Jia Z, Yao C, Jia S, Wang F, Wang S, Zhao Z, et al. Supercontinuum generation covering the entire 0.4-5 $\mu \mathrm{m}$ transmission window in a tapered ultra-high numerical aperture all-solid fluorotellurite fiber. Laser Physics Letters. 2018; 15(2): 025102.

11. Rhonehouse DL, Zong J, Nguyen D, Thapa R, Wiersma K, Smith C, et al. Low loss, wide transparency, robust tellurite glass fibers for mid-IR $(2-5 \mu \mathrm{m})$ applications. In: SPIE Security+ Defence. International Society for Optics and Photonics; 2013. p. 88980D-88980D.

12. XiangHua Zhang BBPLCBPJL. Glasses for Seeing Beyond Visible. Chemistry - A European Journal. 2008; 14(2): 432-442.

13. Mouawad O, Strutynski C, Picot-Clémente J, Désévédavy F, Gadret G, Jules J, et al. Optical aging behaviour naturally induced on $\mathrm{As}_{2} \mathrm{~S}_{3}$ microstructured optical fibres. Optical Materials Express. 2014; 4(10): 2190-2203. 
14. Mouawad O, Amrani F, Kibler B, Picot-Clémente J, Strutynski C, Fatome J, et al. Impact of optical and structural aging in $\mathrm{As}_{2} \mathrm{~S} 3$ microstructured optical fibers on mid-infrared supercontinuum generation. Optics Express. 2014; 22(20): 23912-23919.

15. Toupin P, Brilland L, Mechin D, Adam J, Troles J. Optical Aging of Chalcogenide Microstructured Optical Fibers. Lightwave Technology, Journal of. 2014 July; 32(13): 24282432.

16. Churbanov M, Moiseev A, Chilyasov A, Dorofeev V, Kraev I. Production of high-purity $\mathrm{TeO}_{2}-\mathrm{ZnO}$ and $\mathrm{TeO}_{2}-\mathrm{WO}_{3}$ glasses with the reduced content of OH-groups. Journal of Optoelectronics and Advanced Materials. 2007; 9(10): 3229-3234.

17. Dorofeev VV, Moiseev AN, Churbanov MF, Snopatin GE, Chilyasov AV, Kraev IA, et al. High-purity $\mathrm{TeO}_{2}-\mathrm{WO}_{3}-\left(\mathrm{La}_{2} \mathrm{O}_{3}, \mathrm{Bi}_{2} \mathrm{O}_{3}\right)$ glasses for fiber-optics. Optical Materials. 2011; (12): $1911-1915$.

18. Feng X, Shi J, Segura M, White NM, Kannan P, Calvez L, et al. Towards Water-Free Tellurite Glass Fiber for 2-5 $\mu \mathrm{m}$ Nonlinear Applications. Fibers. 2013;1(3):70-81.

19. O'Donnell M, Miller C, Furniss D, Tikhomirov V, Seddon A. Fluorotellurite glasses with improved mid-infrared transmission. Journal of non-crystalline solids. 2003; 331(1): 48-57.

20. Massera J, Haldeman A, Jackson J, Rivero-Baleine C, Petit L, Richardson K. Processing of Tellurite-Based Glass with Low OH Content. Journal of the American Ceramic Society. 2011; 94(1): 130-136.

21. Savelii I, Desevedavy F, Jules JC, Gadret G, Fatome J, Kibler B, et al. Management of $\mathrm{OH}$ absorption in tellurite optical fibers and related supercontinuum generation. Optical Materials. 2013; 35(8): 1595-1599.

22. Thapa R, Rhonehouse D, Nguyen D, Wiersma K, Smith C, Zong J, et al. Mid-IR supercontinuum generation in ultra-low loss, dispersion-zero shifted tellurite glass fiber with extended coverage beyond $4.5 \mu \mathrm{m}$. In: SPIE Security+ Defence. International Society for Optics and Photonics; 2013. p. 889808-889808.

23. Wang J, Prasad S, Kiang K, Pattnaik R, Toulouse J, Jain H. Source of optical loss in tellurite glass fibers. Journal of Non-Crystalline Solids. 2006; 352(6-7): 510-513.

24. Savelii I, Mouawad O, Fatome J, Kibler B, Désévédavy F, Gadret G, et al. Mid-infrared 2000-nm bandwidth supercontinuum generation in suspended-core microstructured Sulfide and Tellurite optical fibers. Optics Express. 2012; 20(24): 27083-27093. 
25. Boivin $M$, El-Amraoui $M$, Ledemi $Y$, Célarié $F$, Vallée $R$, Messaddeq $Y$. Thermal stress analysis and supercontinuum generation in germanate-tellurite composite fibers. Optical Materials Express. 2016; 6(5): 1653-1662.

26. Kedenburg S, Steinle T, Mörz F, Steinmann A, Nguyen D, Rhonehouse D, et al. Solitonic supercontinuum of femtosecond mid-IR pulses in W-type index tellurite fibers with two zero dispersion wavelengths. APL Photonics. 2016; 1(8): 086101.

27. Kedenburg S, Strutynski C, Kibler B, Froidevaux P, Désévédavy F, Gadret G, et al. High repetition rate mid-infrared supercontinuum generation from 1.3 to $5.3 \mu \mathrm{m}$ in robust stepindex tellurite fibers. JOSA B. 2017; 34(3) : 601-607.

28. Strutynski C, Picot-Clémente J, Lemiere A, Froidevaux P, Désévédavy F, Gadret G, et al. Fabrication and characterization of step-index tellurite fibers with varying numerical aperture for near- and mid-infrared nonlinear optics. J Opt Soc Am B. 2016 ; 33(11): 12-18.

29. Petit L, Cardinal T, Videau JJ, Durand E, Canioni L, Martines M, et al. Effect of niobium oxide introduction on erbium luminescence in borophosphate glasses. Optical Materials. 2006; 28(3): 172-180.

30. Rhonehouse DL, Chavez-Pirson A. Low-loss UV to mid IR optical tellurium oxide glass and fiber for linear, non-linear and active devices. 2014. US Patent 8, 805, 133.

31. Repelin Y, Proust C, Husson E, Beny J. Vibrational spectroscopy of the C-form of yttrium sesquioxide. Journal of Solid-State Chemistry. 1995; 118(1): 163-169.

32. Smayev M, Dorofeev V, Moiseev A, Okhrimchuk A. Femtosecond laser writing of a depressed cladding single mode channel waveguide in high-purity tellurite glass. Journal of Non-Crystalline Solids. 2018; 480: 100-106.

33. Ebendorff-Heidepriem H, Kuan K, Oermann MR, Knight K, Monro TM. Extruded tellurite glass and fibers with low $\mathrm{OH}$ content for mid-infrared applications. Opt Mater Express. 2012 Apr; 2(4): 432-442.

34. Humbach O, Fabian $\mathrm{H}$, Grzesik U, Haken U, Heitmann W. Analysis of $\mathrm{OH}$ absorption bands in synthetic silica. Journal of non-crystalline solids. 1996; 203: 19-26.

35. Stolper E. Water in silicate glasses: an infrared spectroscopic study. Contributions to Mineralogy and Petrology. 1982; 81(1): 1-17.

36. Anashkina EA, Dorofeev VV, Koltashev VV, Kim AV. Development of $\mathrm{Er}^{3+}$-doped highpurity tellurite glass fibers for gain-switched laser operation at $2.7 \mu \mathrm{m}$. Optical Materials Express. 2017; 7(12): 4337-4351. 
37. Tatarintsev B, Yakhkind A. The water content in tellurite glasses and its effect on infrared transmission. Optikomekhanicheskaya promyshlennost. 1975; 3: 40-43.

38. NEMEC L, Götz J. Infrared absorption of $\mathrm{OH}-$ in E glass. Journal of the American Ceramic Society. 1970; 53(9): 526-526.

39. Lide DR. Handbook of Chemistry and Physics, 90th. CRC Press LLC: Boca Raton, FL; 2010.

40. Samsonov G. The oxide handbook; Springer Science. 2013

41. Washburn EW. International Critical Tables of Numerical Data, Physics, Chemistry and Technology (1st Electronic Edition), Knovel. 1926 - 1930; 2003.

42. Karabulut M, Marasinghe GK, Click CA, Metwalli EE, Brow RK, Booth $\mathrm{CH}$, et al. XAFS investigation of platinum impurities in phosphate glasses. Journal of the American Ceramic Society. $2002 ; 85(5)$ : 1093-1099.

43. Veber P. Cristallogenèse de $\mathrm{TeO}_{2}$ par la méthode de Bridgman: mise en évidence d'un processus catalytique de dissociation et solution apportée. Dijon; 2005.

44. Ballato J, Ebendorff-Heidepriem H, Zhao J, Petit L, Troles J. Glass and process development for the next generation of optical fibers: A review. Fibers. 2017;5(1):11.

45. Ebendorff-Heidepriem $H$, Ruan Y, Ji H, Greentree AD, Gibson BC, Monro TM. Nanodiamond in tellurite glass Part I: origin of loss in nanodiamond-doped glass. Optical Materials Express. 2014; 4(12): 2608-2620.

46. Joshi $\mathrm{P}$, Richards $\mathrm{B}$, Jha $\mathrm{A}$. Reduction of $\mathrm{OH}$ - ions in tellurite glasses using chlorine and oxygen gases. Journal of Materials Research. 2013; 28(23): 3226-3233.

47. Feng $\mathrm{X}$, Tanabe S, Hanada T. Hydroxyl groups in erbium-doped germanotellurite glasses. Journal of non-crystalline solids. 2001; 281(1): 48-54.

48. Lin A, Zhang A, Bushong EJ, Toulouse J. Solid-core tellurite glass fiber for infrared and nonlinear applications. Optics Express. 2009; 17(19): 16716-16721.

49. Moiseev A, Dorofeev V, Chilyasov A, Kraev I, Churbanov M, Kotereva T, et al. Production and properties of high purity $\mathrm{TeO}_{2}-\mathrm{ZnO}-\mathrm{Na}_{2} \mathrm{O}-\mathrm{Bi}_{2} \mathrm{O}_{3}$ and $\mathrm{TeO}_{2}-\mathrm{WO}_{3}-\mathrm{La}_{2} \mathrm{O}_{3}-\mathrm{MoO}_{3}$ glasses. Optical Materials. 2011.

50. Yue J, Xue T, Huang F, Liao M, Ohishi Y. Thermally stable mid-infrared fluorotellurite glass with low OH content. Journal of Non-Crystalline Solids. 2015; 408: 1-6. 
51. Lezal D, Pedlikova J, Kostka P, Bludska J, Poulain M, Zavadil J. Heavy metal oxide glasses: preparation and physical properties. Journal of non-crystalline solids. 2001; 284(1): 288-295.

52. Lin A, Ryasnyanskiy A, Toulouse J. Fabrication and characterization of a water-free mid-infrared fluorotellurite glass. Optics Letters. 2011; 36(5): 740-742.

53. Yousef $E$, Hotzel $M$, Rüssel $C$. Linear and non-linear refractive indices of tellurite glasses in the system $\mathrm{TeO}_{2}-\mathrm{WO}_{3}-\mathrm{ZnF}_{2}$. Journal of non-crystalline solids. 2004; 342(1-3): 8288.

54. Sidebottom DL, Hruschka MA, Potter B, Brow RK. Structure and optical properties of rare earth-doped zinc oxyhalide tellurite glasses. Journal of non-crystalline solids. 1997; 222: 282-289.

55. Zhan H, Shi T, Zhang A, Zhou Z, Si J, Lin A. Nonlinear characterization on mid-infrared fluorotellurite glass fiber. Materials Letters. 2014; 120: 174-176.

56. O'Donnell M, Furniss D, Tikhomirov V, Seddon A. Low loss infrared fluorotellurite optical fibre. Physics and Chemistry of Glasses-European Journal of Glass Science and Technology Part B. 2006; 47(2): 121-126.

57. El Sayed SY. Characterization of oxyfluoride tellurite glasses through thermal, optical and ultrasonic measurements. Journal of Physics D: Applied Physics. 2005; 38(21): 3970.

58. Sahar $\mathrm{M}$, Jehbu $\mathrm{A}$, Karim $\mathrm{M}$. $\mathrm{TeO}_{2}-\mathrm{ZnO}-\mathrm{ZnCl}_{2}$ glasses for IR transmission. Journal of non-crystalline solids. 1997; 213: 164-167.

59. Sahar $\mathrm{M}$, Noordin N. Oxychloride glasses based on the $\mathrm{TeO}_{2}-\mathrm{ZnO}-\mathrm{ZnCl}_{2}$ system. Journal of non-crystalline solids. 1995; 184: 137-140.

60. Feng $X$, Shi J, Segura M, White NM, Kannan P, Loh WH, et al. Halo-tellurite glass fiber with low $\mathrm{OH}$ content for $2-5 \mu \mathrm{m}$ mid-infrared nonlinear applications. Optics express. 2013; 21(16): 18949-18954.

61. Scholze H. Glass: nature, structure, and properties. Springer Science \& Business Media; 2012.

62. Ernsberger F. Molecular water in glass. Journal of the American Ceramic Society. 1977; 60(1-2): 91-92.

63. Ryskin YI. The structure and infrared spectra of acid silicates. Izv Akad Nauk SSSR, Neorg Mater. 1971; 7: 375-90.

64. Fuxi G. Optical and spectroscopic properties of glass. Springer; 1992. 
65. Zorin E, Churbanov M, Snopatin G, Grishin I, Petrova T, Plotnichenko V. Microinhomogeneities in tellurite glasses. Inorganic materials. 2005; 41(7): 775-778.

66. Tikhomirov V, Ronchin S, Montagna M, Ferrari M, Furniss D. Intrinsic Defect Related Photoluminescence in $\mathrm{TeO}_{2}$-Based Glasses. physica status solidi (a). 2001; 187(1): R4-R6.

67. Tikhomirov V, Seddon A, Furniss D, Ferrari M. Intrinsic defects and glass stability in $\mathrm{Er}^{3+}$ doped $\mathrm{TeO}_{2}$ glasses and the implications for $\mathrm{Er}^{3+}$-doped tellurite fiber amplifiers. Journal of non-crystalline solids. 2003; 326: 296-300.

68. Miyazawa S, Kondo S. Preparation of paratellurite $\mathrm{TeO}_{2}$. Materials Research Bulletin. 1973; 8(10): 1215-1221.

69. Moiseev AN; Method for purifying tellurium dioxide. RF patent 2301197; 2007.

70. Yakovlev A, Snetkov I, Dorofeev V, Motorin S. Magneto-optical properties of highpurity zinc-tellurite glasses. Journal of Non-Crystalline Solids. 2018; 480: 90-94.

71. Yatsenko YP, Nazaryants VO, Kosolapov AF, Astapovich MS, Plotnichenko VG, Dianov $\mathrm{EM}$, et al. Dispersion and guidance characteristics of microstructured $68 \mathrm{TeO}_{2}-22 \mathrm{WO}_{3}-8 \mathrm{La}_{2} \mathrm{O}_{3}-$ $2 \mathrm{Bi}_{2} \mathrm{O}_{3}$ glass fibres for supercontinuum generation. Quantum Electronics. 2010; 40(6): 513.

72. Saad M. Fluoride glass fiber: state of the art. In: Proceedings of SPIE. vol. 7316; 2009. p. $73160 N$.

73. Saad M. High purity fluoride glass synthesis: a review. In: Proceedings of SPIE. vol. 7228; 2009. p. $72280 G$.

74. Boivin M, El-Amraoui M, Poliquin S, Vallée R, Messaddeq Y. Advances in methods of purification and dispersion measurement applicable to tellurite-based glasses. Optical Materials Express. 2016; 6(4): 1079-1086.

75. Liao G, Chen Q, Xing J, Gebavi H, Milanese D, Fokine M, et al. Preparation and characterization of new fluorotellurite glasses for photonics application. Journal of noncrystalline solids. 2009; 355(7): 447-452.

76. Shi H, Feng X, Tan F, Wang P, Wang P. Multi-watt mid-infrared supercontinuum generated from a dehydrated large-core tellurite glass fiber. Optical Materials Express. 2016; 6(12): 3967-3976.

77. Wang R, Meng X, Yin F, Feng Y, Qin G, Qin W. Heavily erbium-doped low-hydroxyl fluorotellurite glasses for $2.7 \mu \mathrm{m}$ laser applications. Optical Materials Express. 2013; 3(8): 1127-1136. 
78. Jia S, Yao C, Zhao Z, Jia Z, Qin G, Ohishi Y, et al. Flat supercontinuum generation from 1028-2804 nm in an all-solid fluorotellurite fiber. Laser Physics Letters. 2018; 15(11): 115104.

79. Yao C, He C, Jia Z, Wang S, Qin G, Ohishi Y, et al. Holmium-doped fluorotellurite microstructured fibers for $2.1 \mu \mathrm{m}$ lasing. Optics letters. 2015; 40(20): 4695-4698.

80. Picot-Clemente J, Strutynski C, Amrani F, Désévédavy F, Jules J, Gadret G, et al. Enhanced supercontinuum generation in tapered tellurite suspended core fiber. Optics Communications. 2015.

81. Strutynski C, Picot-Clémente J, Désévédavy F, Jules JC, Gadret G, Kibler B, et al. Compact supercontinuum sources based on tellurite suspended core fibers for absorption spectroscopy beyond 2 Mm. Laser Physics Letters. 2016; 13(7): 075402.

82. Yao C, Jia Z, Li Z, Jia S, Zhao Z, Zhang L, et al. High-power mid-infrared supercontinuum laser source using fluorotellurite fiber. Optica. 2018; 5(10): 1264-1270.

83. Savelii I. Fibres optiques à coeur supendu en verre d'oxyde de tellure et génération d'effets non linéaires dans l'infrarouge au-delà de 2 microns. Université de Bourgogne; 2012. 84. Strutynski C. Fibres tellurites pour sources supercontinuum infrarouges: gestion des profils opto-géométriques et des absorptions extrinsèques. Université de Bourgogne; 2016.

85. Li Z, Yao C, Jia Z, Wang F, Qin G, Ohishi Y, et al. Broadband supercontinuum generation from 600 to $5400 \mathrm{~nm}$ in a tapered fluorotellurite fiber pumped by a $2010 \mathrm{~nm}$ femtosecond fiber laser. Applied Physics Letters. 2019; 115(9): 091103.

86. Mandal AK, Sen R. Optimization of melting parameters and minimizing $\mathrm{OH}$ content in $\mathrm{SiO}_{2}-\mathrm{B}_{2} \mathrm{O}_{3}-\mathrm{Na}_{2} \mathrm{O}-\mathrm{BaO}$ glass system in microwave heating. International Journal of Applied Glass Science. 2019; 10(1): 83-91.

87. Thompson D, Danto S, Musgraves J, Wachtel P, Giroire B, Richardson K. Microwave assisted synthesis of high purity $\mathrm{As}_{2} \mathrm{Se}_{3}$ chalcogenide glasses. Physics and Chemistry of Glasses-European Journal of Glass Science and Technology Part B. 2013; 54(1): 27-34.

88. Birnboim A, Gershon D, Calame J, Birman A, Carmel Y, Rodgers J, et al. Comparative study of microwave sintering of zinc oxide at $2.45,30$, and $83 \mathrm{GHz}$. Journal of the American Ceramic Society. 1998; 81(6): 1493-1501.

89. Sanders S. Wavelength-agile fiber laser using group-velocity dispersion of pulsed super-continua and application to broadband absorption spectroscopy. Applied Physics B. 2002; 75(6-7): 799-802. 
90. Parriaux A, Hammani K, Millot G. Two-micron all-fibered dual-comb spectrometer based on electro-optic modulators and wavelength conversion. Communications Physics. 2018; 1(1): 17.

91. Lee KF, Granzow N, Schmidt M, Chang W, Wang L, Coulombier Q, et al. Midinfrared frequency combs from coherent supercontinuum in chalcogenide and optical parametric oscillation. Optics Letters. 2014; 39(7): 2056-2059.

92. Schliesser A, Picqué N, Hänsch TW. Mid-infrared frequency combs. Nature Photonics. 2012; 6(7): 440-449.

93. Hsiung PL, Chen Y, Ko TH, Fujimoto JG, de Matos CJ, Popov SV, et al. Optical coherence tomography using a continuous-wave, high-power, Raman continuum light source. Optics express. 2004; 12(22): 5287-5295.

94. Yamanaka $M$, Kawagoe $H$, Nishizawa $N$. High-power supercontinuum generation using high-repetition-rate ultrashort-pulse fiber laser for ultrahigh-resolution optical coherence tomography in $1600 \mathrm{~nm}$ spectral band. Applied Physics Express. 2016; 9(2): 022701.

95. Wilson R, Tapp H. Mid-infrared spectroscopy for food analysis: recent new applications and relevant developments in sample presentation methods. TrAC Trends in Analytical Chemistry. 1999; 18(2): 85-93.

96. Seddon AB. A prospective for new mid-infrared medical endoscopy using chalcogenide glasses. International Journal of Applied Glass Science. 2011; 2(3): 177-191.

97. Petersen CR, Prtljaga N, Farries M, Ward J, Napier B, Lloyd GR, et al. Mid-infrared multispectral tissue imaging using a chalcogenide fiber supercontinuum source. Optics letters. 2018; 43(5): 999-1002.

98. Petersen CR, Moselund PM, Huot L, Hooper L, Bang O. Towards a table-top synchrotron based on supercontinuum generation. Infrared Physics \& Technology. 2018; 91: 182-186.

99. Labruyère A, Tonello A, Couderc V, Huss G, Leproux P. Compact supercontinuum sources and their biomedical applications. Optical Fiber Technology. 2012; 18(5): 375-378.

100. Ere-Tassou M, Przygodzki C, Fertein E, Delbarre H. Femtosecond laser source for realtime atmospheric gas sensing in the UV-visible. Optics communications. 2003; 220(4-6): 215-221. 


\section{List of tables}

Table 1: Phonon energies of several oxides ${ }^{30,31}$ and corresponding absorption wavelengths

\begin{tabular}{|c|c|c|c|c|c|}
\hline & $\begin{array}{l}\text { Phonon } \\
\text { Energy } \\
\left(\mathrm{cm}^{-1}\right)\end{array}$ & $\begin{array}{c}\text { Fundamental } \\
\text { Absorption } \\
(\mu \mathrm{m})\end{array}$ & $\begin{array}{c}\text { First } \\
\text { harmonic } \\
(\mu \mathrm{m})\end{array}$ & $\begin{array}{c}\text { Second } \\
\operatorname{harmonic}(\mu \mathrm{m})\end{array}$ & $\begin{array}{c}\text { Third } \\
\text { harmonic }(\mu \mathrm{m})\end{array}$ \\
\hline $\mathbf{B}_{2} \mathbf{O}_{3}$ & 1400 & 7.1 & 3.6 & 2.4 & $\begin{array}{ll}1.8 \\
\end{array}$ \\
\hline $\mathbf{P}_{2} \mathbf{O}_{5}$ & 1200 & 8.3 & 4.2 & 2.8 & 2.1 \\
\hline $\mathrm{SiO}_{2}$ & 1100 & 9.1 & 4.5 & 3.0 & 2.3 \\
\hline $\mathrm{WO}_{3}$ & 925 & 10.8 & 5.4 & 3.6 & 2.7 \\
\hline $\mathrm{GeO}_{2}$ & 900 & 11.1 & 5.6 & 3.7 & 2.8 \\
\hline $\mathrm{Nb}_{2} \mathrm{O}_{5}$ & 860 & 11.6 & 5.8 & 3.9 & 2.9 \\
\hline $\mathrm{TeO}_{2}$ & 650 & 15.4 & 7.7 & 5.1 & 3.8 \\
\hline $\mathbf{Y}_{2} \mathbf{O}_{3}$ & 590 & 16.9 & 8.5 & 5.6 & 4.2 \\
\hline $\mathbf{T a}_{2} \mathbf{O}_{5}$ & 550 & 18.2 & 9.1 & 6.1 & 4.5 \\
\hline $\mathrm{Ga}_{2} \mathrm{O}_{3}$ & 500 & 20.0 & 10.0 & 6.7 & 5.0 \\
\hline $\mathbf{L a}_{2} \mathbf{O}_{3}$ & 450 & 22.2 & 11.1 & 7.4 & 5.6 \\
\hline $\mathrm{ZnO}$ & 235 & 42.6 & 21.3 & 14.2 & 10.6 \\
\hline $\mathbf{B i}_{2} \mathbf{O}_{3}$ & 235 & 42.6 & 21.3 & 14.2 & 10.6 \\
\hline $\mathrm{BaO}$ & 200 & 50.0 & 25.0 & 16.7 & 12.5 \\
\hline PbO & 180 & 55.6 & 27.8 & 18.5 & 13.9 \\
\hline
\end{tabular}


Table 2: Melting temperature of metals and oxides considered in this work ${ }^{39}$. Ebullition temperatures are not mentioned because they are beyond the range of interest, dec: decompose.

\begin{tabular}{|c|c|}
\hline Compound & Melting temperature $\left({ }^{\circ} \mathrm{C}\right)$ \\
\hline $\mathrm{Rh}$ & 1964 \\
\hline $\mathrm{Rh}_{2} \mathrm{O}_{3}$ & 1100 \\
\hline RhO & 1121 \\
\hline $\mathrm{Rh}_{2} \mathrm{O}$ & 1127 \\
\hline $\mathrm{Pt}$ & 1768 \\
\hline PtO & 507 dec \\
\hline $\mathrm{PtO}_{2}$ & $450 \mathrm{dec}$ \\
\hline $\mathrm{Pt}_{3} \mathrm{O}_{4}$ & $600 \mathrm{dec}$ \\
\hline $\mathrm{Au}$ & 1064 \\
\hline $\mathrm{Au}_{2} \mathrm{O}$ & $200 \mathrm{dec}$ \\
\hline \multicolumn{2}{|l|}{$\mathrm{Au}_{2} \mathrm{O}_{3}$} \\
\hline Al & 660 \\
\hline $\mathrm{Al}_{2} \mathrm{O}_{3}$ & 2050 \\
\hline Te & 449.5 \\
\hline $\mathrm{TeO}_{2}$ & 733 \\
\hline $\mathrm{ZnO}$ & 1975 \\
\hline $\mathrm{ZnF}_{2}$ & 872 \\
\hline $\mathrm{Na}_{2} \mathrm{CO}_{3}$ & 856 \\
\hline $\mathrm{Na}_{2} \mathrm{O}$ & 1134 \\
\hline
\end{tabular}


Table 3: Assignment of absorption bands observed in a $0.2 \mathrm{~mm}$ thick $80 \mathrm{TeO}_{2}-10 \mathrm{Na}_{2} \mathrm{O}-$ $10 \mathrm{ZnO}$ (at \%) glass sample ${ }^{19}$

\begin{tabular}{|c|c|c|}
\hline Band/ $/ \mu \mathrm{m}$ & Comments & References \\
\hline$\approx 3.03$ & $\begin{array}{l}\text { Stretching mode of free Te-OH groups and/or } \\
\text { stretching mode of molecular water }\end{array}$ & $61-63$ \\
\hline$\approx 3.27$ & $\begin{array}{l}\text { Stretching mode of weak hydrogen-bonded } \\
\text { Te-OH groups }\end{array}$ & 61,63 \\
\hline$\approx 4.37$ & $\begin{array}{l}\text { Stretching mode of strong hydrogen-bonded } \\
\text { Te-OH groups }\end{array}$ & 61,63 \\
\hline$\approx 6.45$ & $\begin{array}{l}\text { First overtone of O-Te-O symmetric stretch } \\
\left(2 \times 790=1580 \mathrm{~cm}^{-1}\right) \text { and } / \text { or bending mode of } \\
\text { molecular water }\end{array}$ & $62-64$ \\
\hline$\approx 7.3$ & $\begin{array}{l}\text { Combination of asymmetric stretch of O-Te-O } \\
\text { or Te-O and }\left[\mathrm{TeO}_{6}\right] \text { group vibration }(730+610 \\
\left.=1340 \mathrm{~cm}^{-1}=7.46 \mu \mathrm{m}\right)\end{array}$ & 64 \\
\hline$\approx 8.26$ & $\begin{array}{l}\text { First overtone of [TeO6] group }(2 \times 610=1220 \\
\left.\mathrm{cm}^{-1}=8.20 \mu \mathrm{m}\right)\end{array}$ & 64 \\
\hline$\approx 9.75$ & $\begin{array}{l}\text { Unidentified, possibly first overtone of [TeO6] } \\
\text { group vibration }\left(2 \times 490=980 \mathrm{~cm}^{-1}=10.20 \mu \mathrm{m}\right)\end{array}$ & 64 \\
\hline
\end{tabular}


Table 4: Tellurite glass synthesis studies performed under a controlled atmosphere (glove box, quartz reactor...). Synthesis conditions indicate the temperature in ${ }^{\circ} \mathrm{C}$, the crucible nature (Pt stand for platinum, $\mathrm{Au}$ for gold, $\mathrm{SiO}_{2}$ for quartz, $\mathrm{Al}_{2} \mathrm{O}_{3}$ for corundum) and the type of mold. Compositions are specified by the metallic element of the corresponding oxide: Te, $\mathrm{Zn}, \mathrm{W}, \mathrm{La}, \mathrm{Bi}, \mathrm{Nb}, \mathrm{Er}, \mathrm{Mo}, \mathrm{Na}, \mathrm{Li}, \mathrm{K} ; \mathrm{OH}$ concentration calculated with $\varepsilon(\mathrm{OH})=47.5 \cdot \ln (10)$ L. $\mathrm{mol}^{-1} . \mathrm{cm}^{-137,36}$.

\begin{tabular}{|c|c|c|c|c|}
\hline \multicolumn{2}{|c|}{ Purification methods } & \multicolumn{2}{|c|}{ Results } & \multirow[t]{2}{*}{ References } \\
\hline $\begin{array}{c}\text { Synthesis temperature / } \\
\text { Crucible / mold }\end{array}$ & Composition & $\begin{array}{l}\text { OH Bulk } \\
\text { Absorption and } \\
\text { residual OH } \\
\text { content (ppm } \\
\text { wt) }\end{array}$ & $\begin{array}{l}\text { Fiber loss and residual } \\
\text { OH content (ppm wt) }\end{array}$ & \\
\hline $\begin{array}{c}850-900^{\circ} \mathrm{C} \& \text { Swirling / Pt or Au \& Lid/ } \\
\text { Brass }\end{array}$ & TZNLa & $\begin{array}{c}90 \mathrm{~dB} / \mathrm{m} @ 3.35 \mu \mathrm{m} \\
6.2 \mathrm{ppm}\end{array}$ & $\begin{array}{l}0.1 \mathrm{~dB} / \mathrm{m} @ 1.2 \mu \mathrm{m} \\
1.7 \mathrm{~dB} / \mathrm{m} @ 2.4 \mu \mathrm{m}\end{array}$ & 33 \\
\hline $800^{\circ} \mathrm{C} / \mathrm{Pt} \& \mathrm{Pt}$ stirrer / metallic & $\begin{array}{l}\text { TWLa, TP, TG, TZ, } \\
\text { TW, TWB, TSbP, } \\
\text { TBaSe }\end{array}$ & - & - & 65 \\
\hline Pt-5\%Au(wt) or Au \& lid / - / - & TZN-Er & - & - & 66,67 \\
\hline $800-850^{\circ} \mathrm{C} 3 \mathrm{~h} / \mathrm{Au}$ or Pt / Brass & TZN & - & $0.24 \mathrm{~dB} / \mathrm{m} @ 1.55 \mu \mathrm{m}$ & 48 \\
\hline
\end{tabular}


Table 5: Tellurite glass purification studies by means of homemade chemicals; all the reported investigations here have been performed under a controlled atmosphere (glove box, quartz reactor...). Purification methods are specified according to the following: PD: PreDrying, DR: Desiccant Reagent, HM: Homemade starting products. Synthesis conditions indicate the temperature in ${ }^{\circ} \mathrm{C}$, the crucible nature (Pt stand for platinum, Au for gold, $\mathrm{SiO}_{2}$ for quartz, $\mathrm{Al}_{2} \mathrm{O}_{3}$ for corundum) and the type of mold. Compositions are specified by the metallic element of the corresponding oxide: $\mathrm{Te}, \mathrm{Zn}, \mathrm{W}, \mathrm{La}, \mathrm{Bi}, \mathrm{Nb}, \mathrm{Er}, \mathrm{Mo}, \mathrm{Na}, \mathrm{Li}, \mathrm{K} ; \mathrm{OH}$ concentration calculated with $\varepsilon(\mathrm{OH})=47.5 \cdot \ln (10) \mathrm{L}_{\mathrm{mol}} \mathrm{m}^{-1} \cdot \mathrm{cm}^{-1} 37,36$.

\begin{tabular}{|c|c|c|c|c|}
\hline \multicolumn{2}{|l|}{ Purification methods } & \multicolumn{2}{|c|}{ Results } & \multirow[t]{2}{*}{ References } \\
\hline $\begin{array}{l}\text { Purification method / synthesis } \\
\text { temperature / Crucible / mold }\end{array}$ & $\begin{array}{l}\text { Compositi } \\
\text { on }\end{array}$ & $\begin{array}{l}\text { OH Bulk } \\
\text { Absorption and } \\
\text { residual OH } \\
\text { content (ppm } \\
\text { wt) }\end{array}$ & $\begin{array}{l}\text { Fiber loss } \\
\text { and } \\
\text { residual } \mathrm{OH} \\
\text { content }\end{array}$ & \\
\hline $\begin{array}{c}\mathrm{HM} \\
800^{\circ} \mathrm{C} / \mathrm{Au}\end{array}$ & $\begin{array}{l}\text { TeBiZLi and } \\
\text { TeBiZnNa }\end{array}$ & - & $\begin{array}{l}0.05 \mathrm{~dB} / \mathrm{m} \\
@ 1.2 \mu \mathrm{m}\end{array}$ & 7 \\
\hline $\begin{array}{c}\text { PD }\left(500-600^{\circ} \text { primary vacuum) \& HM }\right. \\
\quad / 800-850^{\circ} \mathrm{C}, 1-4 \mathrm{~h}, 35 \mathrm{~g}-50 \mathrm{~g} / \mathrm{Pt}\end{array}$ & $\begin{array}{l}\text { TZ and TW, } \\
\text { TWLA }\end{array}$ & $\begin{array}{c}0.004 \mathrm{~cm}^{-1} @ 3 \mu \mathrm{m} \\
(0.119 \mathrm{ppm}) \\
0.00117 \mathrm{~cm}^{-1} \text { for } \\
\text { driest } 0.78 \mathrm{~T}-0.22 \mathrm{~W} \\
(0.035 \mathrm{ppm})\end{array}$ & - & 16 \\
\hline $\begin{array}{c}\text { PD (primary vacuum or } \mathrm{O}_{2} \text { flux } \\
\text { Several hours) \& } \mathrm{HM} \& \text { DR for some samples / } \\
800^{\circ} \mathrm{C} / \mathrm{Pt} \text { or } \mathrm{Au} / \mathrm{SiO}_{2}\end{array}$ & $\begin{array}{l}\text { TeW, TeWLa, } \\
\text { TeWLaBa }\end{array}$ & $\begin{array}{c}0.001 \mathrm{~cm}^{-1} @ 2.95 \\
\mu \mathrm{m} \\
\text { With DR } \\
(0.030 \mathrm{ppm})\end{array}$ & $\begin{array}{c}0.04 \mathrm{~dB} / \mathrm{m} @ 2 \\
\mu \mathrm{m} \\
0.28 \mathrm{~dB} / \mathrm{m} @ \\
2.6 \mu \mathrm{m}\end{array}$ & 17 \\
\hline $\begin{array}{l}\text { PD (primary vacuum or } \mathrm{O}_{2} \text { flux } \\
\text { Several hours) \& } \mathrm{HM} \& \mathrm{DR} / \\
800^{\circ} \mathrm{C} / \mathrm{Pt} \text { or } \mathrm{Au} / \mathrm{SiO}_{2}\end{array}$ & $\begin{array}{l}\text { TeW, TeWLa, } \\
\text { TeZnNaBa, } \\
\text { TeWLaMo }\end{array}$ & $\begin{array}{c}0.001 \mathrm{~cm}^{-1} @ 2.95 \\
\mu \mathrm{m} \\
\text { With DR } \\
(0.030 \mathrm{ppm})\end{array}$ & $\begin{array}{c}0.2 \mathrm{~dB} / \mathrm{m} @ \\
2.1 \mu \mathrm{m}\end{array}$ & 49 \\
\hline $\begin{array}{c}\mathrm{HM} \\
800^{\circ} \mathrm{C} \text { stirring } / \mathrm{Pt} / \mathrm{SiO}_{2}\end{array}$ & $\begin{array}{l}\text { TeZn, TeZnNa } \\
\text { and TeZnLaNa }\end{array}$ & $\begin{array}{c}0.004 \mathrm{~cm}^{-1} @ 3.4 \mu \mathrm{m} \\
(0.119 \mathrm{ppm})\end{array}$ & - & 70 \\
\hline $\begin{array}{c}\mathrm{HM} \\
800^{\circ} \mathrm{C} \text { stirring / Pt or } \mathrm{Au} / \mathrm{SiO}_{2}\end{array}$ & $\begin{array}{c}\text { TeWLa and } \\
\text { TeWBi }\end{array}$ & $\begin{array}{c}\text { TWL } \\
0.15 \mathrm{~cm}^{-1} @ 3 \mu \mathrm{m} \\
(4.48 \mathrm{ppm})\end{array}$ & & 32 \\
\hline $\begin{array}{c}\text { HM } \\
800^{\circ} \mathrm{C} \text { stirring / Pt or Au }\end{array}$ & $\begin{array}{c}\text { TeWLa, } \\
\text { TeWLaBiEr }\end{array}$ & $\begin{array}{c}0.001 \mathrm{~cm}-1 \text { at } 3.3 \\
\mu \mathrm{m} \\
(30 \mathrm{ppb})\end{array}$ & $\begin{array}{c}8 \mathrm{~dB} / \mathrm{m} \text { at } \\
3.3 \mu \mathrm{m} \\
\text { Step index } \\
\text { fiber } \\
\text { (550 ppb wt) }\end{array}$ & 36 \\
\hline
\end{tabular}




\begin{tabular}{|l|c|c|c|c|}
\hline $\mathrm{DR} / 800^{\circ} \mathrm{C} / \mathrm{Pt} / \mathrm{SiO}_{2}$ & $\mathrm{TWLaBi}$ & $0.001 \mathrm{~cm}^{-1} @ 2.95$ & & 71 \\
$\mu \mathrm{m}$ & & & \\
& & $(69 \mathrm{ppb})$ & & \\
\hline
\end{tabular}


Table 6: Tellurite glasses purification through the RAP method. All the reported investigations here have been performed under a controlled atmosphere (glove box, quartz reactor...). Purification methods are specified according to the following initials: PD: Pre-Drying, DR: Desiccant Reagent, HM: Homemade starting products, RAP: Reactive Atmosphere Processing. Synthesis conditions indicate the temperature in ${ }^{\circ} \mathrm{C}$, the crucible nature (Pt stand for platinum, $\mathrm{Au}$ for gold, $\mathrm{SiO}_{2}$ for quartz, $\mathrm{Al}_{2} \mathrm{O}_{3}$ for corundum) and the type of mold. Compositions are specified by the metallic element of the corresponding oxides: $T e, \mathrm{Zn}, \mathrm{W}$, $\mathrm{La}, \mathrm{Bi}, \mathrm{Nb}, \mathrm{Er}, \mathrm{Mo}, \mathrm{Na}, \mathrm{Li}, \mathrm{K} \ldots ; \mathrm{OH}$ concentration calculated with $\varepsilon(\mathrm{OH})=47.5 \cdot \ln (10) \mathrm{L} . \mathrm{mol}^{-1} . \mathrm{cm}^{-}$ 137,36

\begin{tabular}{|c|c|c|c|}
\hline \multicolumn{2}{|c|}{ Purification methods } & \multirow{2}{*}{$\begin{array}{c}\text { Results } \\
\text { OH Bulk Absorption } \\
\text { and residual OH } \\
\text { content (ppm wt) }\end{array}$} & \multirow[t]{2}{*}{ References } \\
\hline $\begin{array}{l}\text { Purification method / synthesis } \\
\text { temperature / Crucible / mold }\end{array}$ & Composition & & \\
\hline $\begin{array}{c}\text { PD (vacuum } 100-300^{\circ} \mathrm{C} \text { ) } \\
\text { under the RAP }\left(\mathrm{O}_{2}-\mathrm{CCl}_{4}\right) \text { or } \mathrm{DR}(\mathrm{PbCl} 2 \\
\left.\text { substituted by } \mathrm{PbF}_{2}\right) \\
\text { or Addition of } \mathrm{NH}_{4} \mathrm{NO}_{3}, \mathrm{CaCl}_{2}, \mathrm{AlF}_{3} \\
/ 800^{\circ} \mathrm{C} 30^{\prime} \mathrm{O}_{2} / \mathrm{Pt}, \mathrm{Au}, \mathrm{SiO}_{2} \text { or } \mathrm{Al}_{2} \mathrm{O}_{3}\end{array}$ & $\begin{array}{l}\text { TeZn and } \\
\mathrm{TePbPbCl}_{2}\end{array}$ & $\begin{array}{l}\text { At } 3 \mu \mathrm{m}, 0.36 \mathrm{~cm}^{-1} \text { to } 0.16 \\
\mathrm{~cm}^{-1} \text { when } \mathrm{Cl}_{2} \text { atmosphere is } \\
\text { used. } \\
\text { (10.74 to } 4.77 \mathrm{ppm})\end{array}$ & 51 \\
\hline $\begin{array}{c}\text { PD }\left(623-723 \mathrm{~K} \text {-under } \mathrm{O}_{2}-\mathrm{Cl}_{2} 3 \mathrm{~h} 0.5 \mathrm{~L} \cdot \mathrm{min}^{-1}\right) \\
\text { RAP }\left(\mathrm{Cl}_{2}-\mathrm{O}_{2}(10-90 \% \text { vol })\right. \\
/ 1073 \mathrm{~K} \mathrm{O}_{2}-\mathrm{Cl}_{2} / \mathrm{Au} / \text { Brass }\end{array}$ & 80Te10Zn10Na & $\begin{array}{c}0.06 \mathrm{~cm}^{-1} @ 3 \mu \mathrm{m} \\
(1.79 \mathrm{ppm})\end{array}$ & 46 \\
\hline $\operatorname{RAP}\left(\mathrm{CCl}_{4} / \mathrm{O}_{2}\right) / 800-1100^{\circ} \mathrm{C} / \mathrm{Au} \& \mathrm{Al}_{2} \mathrm{O}_{3}$ & TeGeZnYNaEr & $\begin{array}{c}1.5 \mathrm{~cm}^{-1} @ 3 \mu \mathrm{m} \\
44.8 \mathrm{ppm}\end{array}$ & 47 \\
\hline $\begin{array}{c}\text { PD (15h T<Tf starting product + all batch } \\
\left.\text { under vacuum at } 140^{\circ} \mathrm{C}\right) \text { RAP Ar } / \mathrm{F}_{2} 6 \mathrm{~h} \\
@ 600^{\circ} \mathrm{C} \\
/ 1400-1575^{\circ} \mathrm{C}-\mathrm{O}_{2}-1 \mathrm{~h} / \mathrm{Pt} / \mathrm{C}\end{array}$ & $\mathrm{P}_{2} \mathrm{O}_{5}-\mathrm{B}_{2} \mathrm{O}_{3}-\mathrm{Nb}_{2} \mathrm{O}_{5}$ & $\begin{array}{c}1 \mathrm{~cm}^{-1} @ 3 \mu \mathrm{m} \\
(29.8 \mathrm{ppm})\end{array}$ & 29 \\
\hline
\end{tabular}


Table 7: Tellurite glass purification by desiccant reagents studies. All the reported investigations here have been performed under a controlled atmosphere (glove box, quartz reactor...). Purification methods are specified according to the following initials: PD: PreDrying, DR: Desiccant Reagent, HM: Homemade starting products. Synthesis conditions indicate the temperature in ${ }^{\circ} \mathrm{C}$, the crucible nature (Pt stand for platinum, Au for gold, $\mathrm{SiO}_{2}$ for quartz, $\mathrm{Al}_{2} \mathrm{O}_{3}$ for corundum) and the type of mold. Compositions are specified by the metallic element of the corresponding oxides: Te, $\mathrm{Zn}, \mathrm{W}, \mathrm{La}, \mathrm{Bi}, \mathrm{Nb}, \mathrm{Er}, \mathrm{Mo}, \mathrm{Na}, \mathrm{Li}, \mathrm{K} \ldots ; \mathrm{OH}$ concentration calculated with $\varepsilon(\mathrm{OH})=47.5 \cdot \ln (10) \mathrm{L} \cdot \mathrm{mol}^{-1} \cdot \mathrm{cm}^{-137,36}$.

\begin{tabular}{|c|c|c|c|c|}
\hline \multicolumn{2}{|c|}{ Purification methods } & \multicolumn{2}{|c|}{ Result } & \multirow[t]{2}{*}{ References } \\
\hline $\begin{array}{l}\text { Purification method/synthesis } \\
\text { temperature/Crucible/mold }\end{array}$ & Composition & $\begin{array}{l}\text { OH Bulk Absorption and } \\
\text { residual } \mathrm{OH} \text { content } \\
\text { (ppm wt) }\end{array}$ & $\begin{array}{l}\text { Fiber loss and residual } \mathrm{OH} \\
\text { content (ppm wt) }^{\text {b }}\end{array}$ & \\
\hline $\begin{array}{l}\text { DR }\left(\mathrm{ZnF}_{2}, \mathrm{KCl}, \mathrm{NH}_{4} \mathrm{~F}-\mathrm{HF}, \mathrm{ZnO} \text { replaced by } \mathrm{ZnF}_{2}\right. \\
\text { (20\% at) with or a without } \mathrm{NH}_{4} \mathrm{~F}-\mathrm{HF} \text { heat } \\
\text { treatment } \\
\mathrm{K} \text { or } \mathrm{Li} / 15 \mathrm{~h} 500^{\circ} \mathrm{C} \text { for decarbonatation / } \\
45^{\prime} 500^{\circ} \mathrm{C} ; 850^{\circ} \mathrm{C} 5-10^{\prime} \mathrm{O}_{2} / \mathrm{Pt} /-\end{array}$ & $\begin{array}{l}\text { TeBiZn + } \\
(\mathrm{Ba} / \mathrm{K} / \mathrm{Li})\end{array}$ & $\begin{array}{c}<0.5 \mathrm{~cm}^{-1} \\
\left(14.6 \mathrm{ppm} \text { with } \mathrm{ZnF}_{2} \text { and } \mathrm{NH}_{4} \mathrm{H}-\right. \\
\mathrm{HF}-<14.9 \mathrm{ppm}) \\
\mathrm{ZnF}_{2} \text { only: } 1 \mathrm{~cm}^{-1} \\
(29.8 \mathrm{ppm})\end{array}$ & $\begin{array}{l}\text { Background improvement of } \mathrm{O}_{2} \\
\text { rich atmosphere between } 0.8 \\
\text { and } 1.6 \mu \mathrm{m}\end{array}$ & 20 \\
\hline $\begin{array}{c}\text { PD }\left(525-750^{\circ} \mathrm{C} \text { vacuum) \& DR }\left(\mathrm{TeCl}_{4}\right) /\right. \\
800^{\circ} \mathrm{C} \text { (optimized Thermal profile) / Pt / Pt }\end{array}$ & TeW & $\begin{array}{c}7.5 \mathrm{~dB} / \mathrm{m}\left(0.017 \mathrm{~cm}^{-1}\right) @ 3 \mu \mathrm{m} \\
(0.51 \mathrm{ppm})\end{array}$ & & 74 \\
\hline $\begin{array}{c}\text { DR ( } \mathrm{NaCl} \text { and } \mathrm{PbCl}_{2} \text { up to } 20 \% \text { at) / } \\
70 \mathrm{~g}, 700-900^{\circ} \mathrm{C} / \mathrm{Au} / \text { metal }\end{array}$ & $\begin{array}{l}\mathrm{TeZnNa} \& \\
\mathrm{TePbPbCl} 2\end{array}$ & $\begin{array}{c}0.3 \mathrm{~cm}^{-1} @ 3.35 \mu \mathrm{m}(8.9 \mathrm{ppm}) \\
0.16 \mathrm{~cm}^{-1} @ 3.35 \mu \mathrm{m}(4.8 \mathrm{ppm})\end{array}$ & $\begin{array}{c}45 \mathrm{~dB} / \mathrm{m} \mathrm{(3} \mathrm{ppm)} \\
13.5 \mathrm{~dB} / \mathrm{m} \\
(0.93 \mathrm{ppm})\end{array}$ & 60 \\
\hline $\mathrm{DR} / 800^{\circ} \mathrm{C} / \mathrm{Pt} / \mathrm{SiO}_{2}$ & TWLaBi & $\begin{array}{c}0.001 \mathrm{~cm}^{-1} @ 2.95 \mu \mathrm{m} \\
(0.069 \mathrm{ppm})\end{array}$ & & 71 \\
\hline $\begin{array}{c}\mathrm{DR}\left(\mathrm{ZnF}_{2}\right) / 750^{\circ} \mathrm{C} 45^{\prime} \& 800^{\circ} \mathrm{C} 15^{\prime} \\
650^{\circ} \mathrm{C} \text { for casting / } \mathrm{Pt}+\text { lid / Aluminum }\end{array}$ & $\mathrm{TeZnNa}$ & $\begin{array}{c}20 \mathrm{~dB} / \mathrm{m} @ 3.35 \mu \mathrm{m} \\
(1.37 \mathrm{ppm})\end{array}$ & & 19 \\
\hline DR $\left(\mathrm{ZnF}_{2}\right) / 730-825^{\circ} \mathrm{C} 30^{\prime} \&$ Stirring / Pt lid & $\begin{array}{l}\mathrm{TZnF}_{2} \mathrm{PbNb} 0 \% \\
\mathrm{ZnO} \text { (only use of } \\
\mathrm{ZnF}_{2} \text { ) }\end{array}$ & $\begin{array}{c}0.15 \mathrm{~cm}^{-1} @ 3 \mu \mathrm{m} \\
(4.48 \mathrm{ppm})\end{array}$ & & 75 \\
\hline $\begin{array}{c}\mathrm{DR}\left(\mathrm{ZnF}_{2} \text { up to } 5 \% \text { at) / }\right. \\
750-950^{\circ} \mathrm{C} \text { Stirred \& bubbled with flowing gas } \\
/ \mathrm{Au} /-\end{array}$ & TeZnLa & $\begin{array}{c}0.003 \mathrm{~cm}^{-1} @ 3 . \mu \mathrm{m} . \\
(0.21 \mathrm{ppm})\end{array}$ & $\begin{array}{c}<0.5 \mathrm{~dB} / \mathrm{m} \text { up to } 4.2 \mu \mathrm{m} \\
0.25 \mathrm{~dB} / \mathrm{m} @ 3 \mu \mathrm{m} \\
(0.017 \mathrm{ppm})\end{array}$ & 11,30 \\
\hline DR $\left(\mathrm{ZnF}_{2}\right.$ up to $30 \%$ at) $/ 800^{\circ} \mathrm{C}-2 \mathrm{~h}$ & TeZnNa & $\begin{array}{c}0.03 \mathrm{~cm}^{-1} @ 3 \mu \mathrm{m} \\
(2 \mathrm{ppm})\end{array}$ & & 52 \\
\hline $\begin{array}{c}\mathrm{DR}\left(\mathrm{ZnF}_{2}\right) / 750-850^{\circ} \mathrm{C} 30^{\prime}, 700^{\circ} \mathrm{C} \text { casting / } \\
\mathrm{Au} / \mathrm{Graphite}\end{array}$ & TeWZn & & & 53 \\
\hline PD (primary vacuum & TeW, TeWLa, & $0.001 \mathrm{~cm}^{-1} @ 3 \mu \mathrm{m}$ & $<0.6 \mathrm{~dB} / \mathrm{km}$ between 1.4 et 2.4 & 49 \\
\hline
\end{tabular}

\footnotetext{
${ }^{b}$ According to ${ }^{60,60}, \mathrm{OH}$ absorption difference between bulk and fiber may be partly due to residual water adsorbed on bulk surfaces. Churbanov et al ${ }^{16,16}$ and Anashkina et al ${ }^{36,36}$ show that it is necessary to account for this effect for short samples presenting low $\mathrm{OH}$ quantity.
} 


\begin{tabular}{|c|c|c|c|c|}
\hline $\begin{array}{l}\text { Or } \mathrm{O}_{2} \text { flux several hours) \& } \mathrm{DR}\left(\mathrm{BiF}_{3}, \mathrm{WOF}_{4}\right) / \\
\qquad 800^{\circ} \mathrm{C} / \mathrm{Pt} \text { or } \mathrm{Au} / \mathrm{-}\end{array}$ & $\begin{array}{l}\text { TeZnNaBi, } \\
\text { TeWLaMo }\end{array}$ & $\begin{array}{c}(0.030 \text { ppm }) \\
74 \mathrm{~dB} / \mathrm{km} @ 1.55 \mu \mathrm{m}\end{array}$ & $\mu \mathrm{m}$ & \\
\hline DR $\left(\mathrm{BaCl}_{2}\right)$ & TeBaZn & $\begin{array}{c}8 \mathrm{~dB} / \mathrm{m} @ 3.35 \mu \mathrm{m} \\
(0.55 \mathrm{ppm})\end{array}$ & & 76 \\
\hline $\begin{array}{c}\text { PD (35 min - } 130^{\circ} \mathrm{C} \text { under vacuum) \& DR }\left(\mathrm{BaF}_{2}\right. \\
19-38 \% \text { at) } / 900^{\circ} \mathrm{C} 35^{\prime} / \mathrm{Al}_{2} \mathrm{O}_{3} / \text { Copper }\end{array}$ & $\begin{array}{l}\mathrm{TeBaF}_{2} \mathrm{NaEr}(0 \% \\
\mathrm{BaO}) \text { only } \mathrm{BaCl} 2\end{array}$ & $0.0702 \mathrm{~cm}^{-1} @ 2.7 \mu \mathrm{m}$ & & 77 \\
\hline $\begin{array}{c}\left.\text { PD (35 min - } 130^{\circ} \mathrm{C} \text { under vacuum }\right) \\
\& \mathrm{DR}\left(\mathrm{BaF}_{2} 25 \% \text { at }\right) / \\
900^{\circ} \mathrm{C} 35^{\prime} / \mathrm{Al}_{2} \mathrm{O}_{3} / \text { Copper }\end{array}$ & $\begin{array}{c}\mathrm{TeBaF}_{2} \mathrm{YHo} \\
\text { \& } \mathrm{TeAlBCaYSrMg} \text {, } \\
\text { all fluoride except } \\
\text { for } \mathrm{TeO}_{2} \\
\text { (fluorotellurite } \\
\text { glass) }\end{array}$ & $\begin{array}{c}\text { Flat transmission } \\
<1 \mathrm{~dB} / \mathrm{m} @ 4 \mu \mathrm{m} \\
0.0006 \mathrm{~cm}^{-1} \text { between } 3 \text { et } 4 \mu \mathrm{m} \\
(0.018 \mathrm{ppm})\end{array}$ & & 78,79 \\
\hline $\begin{array}{c}\text { PD (vacuum) \& } \mathbf{D R}\left(\mathrm{ZnF}_{2}, \mathrm{PbCl}_{2}, \mathrm{BaF}_{2}, \mathrm{PbF}_{2} \text { and }\right. \\
\left.\mathrm{CaF}_{2}\right) / 700-800^{\circ} \mathrm{C} / \mathrm{O}_{2} \text { bubbling } / \mathrm{Au} / \\
\text { Stainless steel }\end{array}$ & $\begin{array}{c}\text { TeZnNaLa,TeZnLa } \\
\text { with } \mathrm{PbCl}_{2} \& \mathrm{NaF} \\
\& \mathrm{PbF}_{2} \& \mathrm{CaF}_{2} \\
\text { TeZnNb, TeZnW, } \\
\text { TeZnMo with } \mathrm{ZnF}_{2}\end{array}$ & $\begin{array}{c}0.054 \mathrm{~cm}^{-1} @ 3 \mu \mathrm{m} \\
(1.6 \mathrm{ppm})\end{array}$ & & 50 \\
\hline $\begin{array}{c}\text { DR ( } \mathrm{ZnF}_{2}>10 \% \text { at) Room atmosphere / } \\
750-850^{\circ} \mathrm{C} / \mathrm{Au} / \text { Graphite }\end{array}$ & $\mathrm{TeWZnF}_{2}$ & & & 57 \\
\hline $\begin{array}{c}\text { DR ( } \mathrm{ZnCl}_{2}>20 \% \text { at) Room atmosphere / } \\
800-1000^{\circ} \mathrm{C} / \mathrm{Al}_{2} \mathrm{O}_{3} / \text { Brass }\end{array}$ & $\mathrm{TeZnZnCl}_{2}$ & & & 59 \\
\hline DR $\left(\mathrm{ZnF}_{2} 5-10 \%\right.$ at $) / 850^{\circ} \mathrm{C} \mathrm{O}_{2} / \mathrm{Pt} /$ Brass & $\mathrm{TeZnNa}$ & $\begin{array}{c}0.008 \mathrm{~cm}^{-1} @ 3.4 \mu \mathrm{m} \\
(0.24 \mathrm{ppm})\end{array}$ & $\begin{array}{c}5 \% \text { at } \mathrm{ZnF}_{2} \\
14 \mathrm{~dB} / \mathrm{m} @ 3.4 \mu \mathrm{m} \\
(0.96 \mathrm{ppm})\end{array}$ & 21 \\
\hline DR $\left(\mathrm{ZnF}_{2} 5-10 \%\right.$ at $) / 850^{\circ} \mathrm{C} \mathrm{O}_{2} / \mathrm{Pt} /$ Brass & TeZnNa & & $\begin{array}{c}5 \% \text { at } \mathrm{ZnF}_{2} \\
\text { Transmission on fiber up to } 4 \mu \mathrm{m} \\
5 \mathrm{~dB} / \mathrm{m} @ 3.5 \mu \mathrm{m}(0.34 \mathrm{ppm})\end{array}$ & 80 \\
\hline DR $\left(\mathrm{ZnF}_{2} 5-10 \%\right.$ at) $/ 850^{\circ} \mathrm{C} \mathrm{O}_{2} / \mathrm{Pt} /$ Brass & TeZnNa/TeNaGeZ & & $\begin{array}{c}3 \mathrm{~dB} / \mathrm{m} @ 3.5 \mu \mathrm{m} \\
(0.206 \mathrm{ppm})\end{array}$ & 81,27 \\
\hline $\begin{array}{c}\text { DR }\left(\mathrm{BaF}_{2} 20 \% \text { at) \& fluoride cladding } /-\mathrm{N}_{2} /-\right. \\
/-\end{array}$ & $\begin{array}{c}\mathrm{TeBaF}_{2} \mathrm{Y}_{2} \mathrm{O}_{3} / \mathrm{TeAl} \\
\mathrm{BaCaYSrMg} \\
\text { all fluoride except } \\
\text { for } \mathrm{TeO}_{2} \\
\text { (fluorotellurite } \\
\text { glass) }\end{array}$ & & $\begin{array}{c}\text { Core } 20 \% \text { at } \mathrm{BaF}_{2} \\
\text { Clad } 90 \% \text { at fluoride } \\
<2.3 \mathrm{~dB} / \mathrm{m} \text { from } 1.1 \text { to } 4.5 \mu \mathrm{m} \\
(0.07 \mathrm{ppm})\end{array}$ & 82 \\
\hline
\end{tabular}




\section{List of figures captions}

Figure 1: (a) Ellingham diagram of $P t, A u, T e$ and $A$ l for the reactions of oxidation;

(b) $\log \left(P_{\mathrm{O}_{2}} / P^{\circ}\right)$ at the equilibrium versus the temperature.

Figure 2: Transmission spectra of two tellurite glasses of the same composition, prepared in gold or platinum crucible.

Figure 3: Comparison between the absorption coefficient of a tellurite glass made under ambient atmosphere (TZN air), the same glass prepared under a pure $\mathrm{O}_{2}$ atmosphere $\left(T Z \mathrm{~N} \mathrm{O}_{2}\right)^{21}$ and the same composition made under a pure $\mathrm{O}_{2}$ associated to optimized time and temperature conditions. ${ }^{33}$ The TZN glass composition is $80 \mathrm{TeO}_{2}-10 \mathrm{ZnO}-10 \mathrm{Na}_{2} \mathrm{O}$ (mol \%).

Figure 4: (a) $\mathrm{OH}$ absorption coefficient for different bulk tellurite glasses made from homemade ultra-pure starting products and (b) fibers attenuation.

Figure 5: Ellingham diagrams of the reaction between $\mathrm{Cl}_{2}$ and hydrated starting products of TZN glasses; considered reactions are specified in the legend and are written for one mole of $\mathrm{Cl}_{2}$.

Figure 6: Bulk coefficient absorption function of wavelength for tellurite glasses prepared through the RAP 
Figure 7: (a) The Ellingham like diagram of the reaction between $\mathrm{ZnF}_{2}$ and hydrated starting products, considered reactions are specified in the legend. (b) comparison of the Gibbs free energy of the reactions of water with $\mathrm{TeO}_{2}$ and $\mathrm{ZnF}_{2}$. (c) and (d) are the log of the equilibrium constant's plot function of the temperature corresponding to the cases described in figure (a). The region where products or reagents are favored is specified on the figures.

Figure 8: Bulk absorption coefficient as a function of wavelength for tellurite glasses prepared through reagent addition: (a) results showing a low efficiency of the method; (b) moderate efficiency; (c) high efficiency and best results reported, $\mathrm{OH}$ quantity is strongly reduced, this absorption level allows for transmission on meter long samples i.e. fibers.

Figure 9: Reported attenuation measurements recorded by means of the cut back method on fiber samples (length $>50 \mathrm{~cm}$ ) made from glasses prepared through reagent addition, (a) results obtained by different research groups, (b) results we achieved at ICB.

Figure 10: Broadest SC spectra generated in tellurite fibers: green curve is the SC presented in 11, 22 has been obtained by coupling $94 \mathrm{~nJ}$ pulse energy centered at $1.92 \mu \mathrm{m}$ into a fiber showing a W refractive index profile, using a 26 ps source operating at $32 \mathrm{MHz}$; in red the SC obtained by a collaboration between University of Bourgogne and University of Stuttgart ${ }^{27}$ has been generated in the step index tellurite fiber which attenuation is shown in figure 9 (orange curve) ${ }^{28}$ by injecting $3.5 \mathrm{~nJ}$ pulse energy at $2.4 \mu \mathrm{m}$ using a $350 \mathrm{fs}$ source operating at $43 \mathrm{MHz}$ and in black the SC generated by pumping at $3 \mu \mathrm{m}$ with $1.4 \mathrm{~nJ}$ coupled energy in the same fiber than the one which leads to the green SC but with the same pump source as the one used in the case of the red SC i.e. $350 \mathrm{fs}, 43 \mathrm{MHz}^{26}$. The blue SC is generated by 
launching a 196 fs pump - $31 \mathrm{~nJ}$ pulse centered at $2 \mu \mathrm{m}$ in a fluorotellurite fiber ${ }^{85}$ whose attenuation is shown by the blue curve in figure 9(a). For each of the spectra, the 0-dB level corresponds to the maximum detected intensity which typically lies at the pump wavelength. 